\title{
Experience-Dependent Plasticity in Accessory Olfactory Bulb Interneurons following Male-Male Social Interaction
}

\author{
난 Hillary L. Cansler, ${ }^{1,2}$ Marina A. Maksimova, ${ }^{1}$ and $\odot$ Julian P. Meeks ${ }^{1}$ \\ ${ }^{1}$ Department of Neuroscience, and ${ }^{2}$ Neuroscience Graduate Program, Graduate Program of Biomedical Sciences, The University of Texas Southwestern \\ Medical Center, Dallas, Texas 75390
}

Chemosensory information processing in the mouse accessory olfactory system guides the expression of social behavior. After salient chemosensory encounters, the accessory olfactory bulb (AOB) experiences changes in the balance of excitation and inhibition at reciprocal synapses between mitral cells (MCs) and local interneurons. The mechanisms underlying these changes remain controversial. Moreover, it remains unclear whether MC-interneuron plasticity is unique to specific behaviors, such as mating, or whether it is a more general feature of the AOB circuit. Here, we describe targeted electrophysiological studies of AOB inhibitory internal granule cells (IGCs), many of which upregulate the immediate-early gene Arc after male-male social experience. Following the resident-intruder paradigm, Arc-expressing IGCs in acute AOB slices from resident males displayed stronger excitation than nonexpressing neighbors when sensory inputs were stimulated. The increased excitability of Arc-expressing IGCs was not correlated with changes in the strength or number of excitatory synapses with MCs but was instead associated with increased intrinsic excitability and decreased HCN channel-mediated $I_{\mathrm{H}}$ currents. Consistent with increased inhibition by IGCs, MCs responded to sensory input stimulation with decreased depolarization and spiking following resident-intruder encounters. These results reveal that nonmating behaviors drive $\mathrm{AOB}$ inhibitory plasticity and indicate that increased $\mathrm{MC}$ inhibition involves intrinsic excitability changes in Arc-expressing interneurons.

Key words: accessory olfactory bulb; chemical senses; experience-dependent plasticity; interneuron; intrinsic excitability; sensory processing

\section{Significance Statement}

The accessory olfactory bulb (AOB) is a site of experience-dependent plasticity between excitatory mitral cells (MCs) and inhibitory internal granule cells (IGCs), but the physiological mechanisms and behavioral conditions driving this plasticity remain unclear. Here, we report studies of AOB neuronal plasticity following male-male social chemosensory encounters. We show that the plasticity-associated immediate-early gene Arc is selectively expressed in IGCs from resident males following the residentintruder assay. After behavior, Arc-expressing IGCs are more strongly excited by sensory input stimulation and MC activation is suppressed. Arc-expressing IGCs do not show increased excitatory synaptic drive but instead show increased intrinsic excitability. These data indicate that MC-IGC plasticity is induced after male-male social chemosensory encounters, resulting in enhanced MC suppression by Arc-expressing IGCs.

\section{Introduction}

A central goal in neuroscience is to understand how sensory processing in the brain guides behavior. The mammalian accessory

\footnotetext{
Received April 17, 2017; revised June 1, 2017; accepted June 22, 2017.

Author contributions:H.L.C. and J.P.M. designed research;H.L.C. and M.A.M. performed research; J.P.M. contributed unpublished reagents/analytic tools; H.L.C. and J.P.M. analyzed data; H.L.C. and J.P.M. wrote the paper.

This work was funded by the National Institute on Deafness and Other Communication Disorders and the National Institute on Drug Abuse of the National Institutes of Health under award numbers R00-DC-011780 and R01-DC015784 (to J.P.M.), and T32-DA-007290 (to H.L.C.). Partial support was also provided by the National Science Foundation (Grant IOS-1451034; to J.P.M., c0-Principal Investigator). The content is solely the responsibility of the authors and does not necessarily represent the official views of the National Institutes of Health. We thank Jennifer Torres, Salma Ferdous, and Natasha Browder for technical support. We also thank Kimberly Huber and Todd Roberts for critical feedback on the manuscript.
}

olfactory system (AOS) is an attractive neural pathway for studying the processes linking sensation and behavior because the AOS has a relatively linear circuit pathway into the brain and drives a variety of social behaviors (for review, see Liberles, 2014). In the AOS, sensory information is generated in the vomeronasal organ (VNO) and is processed by a single dedicated neural circuit, the accessory olfactory bulb (AOB), before being sent to limbic struc-

The authors declare no competing financial interests.

Correspondence should be addressed to Julian P. Meeks, 5323 Harry Hines Boulevard, MC 9111, NB4.204D, Dallas, TX 75390. E-mail: julian.meeks@utsouthwestern.edu.

DOI:10.1523/JNEUROSCI.1031-17.2017

Copyright $\odot 2017$ the authors $\quad 0270-6474 / 17 / 377240-13 \$ 15.00 / 0$ 
tures, including the medial amygdala and bed nucleus of the stria terminalis (Scalia and Winans, 1975). Animals lacking proper AOS signaling display a range of atypical behaviors, including deficits in predator avoidance (Papes et al., 2010; Pérez-Gómez et al., 2015), courtship (Pankevich et al., 2004; Kimchi et al., 2007; Ferrero et al., 2013), and territorial aggression (Stowers et al., 2002; Chamero et al., 2007; Leinders-Zufall et al., 2014). Though many of these behaviors are considered innate, behavioral and physiological evidence suggests that the $\mathrm{AOB}$ is a site of experiencedependent plasticity. This has been best studied in the context of pregnancy block, in which a female forms a chemosensory memory of her recent mate but remains unexplored in the context of other AOS-mediated social behaviors (Bruce, 1959; Brennan et al., 1990).

There is still much to learn about how the AOB contributes to plasticity in social behaviors. In pregnancy block, one hypothesis proposes that inhibitory gain limits the activation of $\mathrm{AOB}$ projection neurons, called mitral cells (MCs) to the chemosensory cues of a recent mate (for review, see Brennan, 2009). Increased inhibition involves changes at reciprocal dendrodendritic synapses between MCs and AOB interneurons (Brennan et al., 1990; Araneda and Firestein, 2006; Larriva-Sahd, 2008; Brennan, 2009; Smith et al., 2009). It remains unclear whether such inhibition is induced by other social chemosensory encounters, and the specific neuronal populations that contribute to these effects are not yet clear.

Immediate early genes (IEGs) are expressed in recently active neurons and can provide extensive information about the cells and networks that participate in sensory and behavioral experiences (Kawashima et al., 2013; Kim et al., 2015; Vousden et al., 2015). The IEG $A r c$ is both an important plasticity-related gene and a useful marker of neuronal populations engaged by experience (for review, see Shepherd and Bear, 2011). Arc is typically expressed in principal excitatory neurons (cortical and hippocampal pyramidal neurons), where it mediates many forms of experience-dependent synaptic plasticity (Plath et al., 2006; Vazdarjanova et al., 2006; Jakkamsetti et al., 2013). Studies of Arc expression in the AOB show that it is selectively upregulated in subsets of AOB internal granule cells (IGCs), but not MCs, in male and female rodents after mating (Matsuoka et al., 2002a, 2003). Arc expression by interneurons has also been noted in the main olfactory bulb in several studies (Guthrie et al., 2000; Vazdarjanova et al., 2006; Shakhawat et al., 2014). The selective expression of Arc by interneurons is atypical, and studying these populations is likely to provide new insights into the role of Arc in nonprincipal neuronal types.

Here, we report that $A r c$ is selectively expressed in posterior $\mathrm{AOB}$ (pAOB) IGCs of male mice following the resident-intruder territorial aggression assay. Arc upregulation by IGCs required intact vomeronasal signaling, indicating that centrifugal inputs were not sufficient to induce Arc in this behavioral paradigm. Following resident-intruder behavior, Arc-expressing IGCs in resident males showed enhanced network excitation compared with nonexpressing IGCs, while MC activity was suppressed. We investigated the IGC physiological features that underlie their enhanced activity and found no evidence for an increase in excitatory synapse strength or number. Instead, we found that Arc-expressing IGCs display a robust increase in intrinsic excitability compared with other IGCs. Our results show that AOB inhibitory plasticity occurs after nonmating behaviors and reveal cellular mechanisms underlying MC inhibition after chemosensory social encounters.

\section{Materials and Methods}

Mice. All animal procedures were in compliance with the University of Texas Southwestern Institutional Care and Use Committee. Sexually naive adult male mice aged 6-12 weeks were housed on a customized $12 \mathrm{~h}$ light/dark cycle with the lights on from noon until midnight. Food and water were provided ad libitum. Arc-d4EGFP-BAC (a gift from Pavel Osten Cold Spring Harbor Laboratory, Cold Spring Harbor, NY; Grinevich et al., 2009) and $A r c^{\text {tm } 1 S t}$ (Arc ${ }^{-1-}$ or Arc-d2EGFP; stock \#007662, The Jackson Laboratory; RRID:IMSR_JAX:007662; Wang et al., 2006) mice were generous gifts from Kimberly Huber (UT Southwestern Medical Center, Dallas, TX). Trpc2 $2^{\text {tm1Dlc }}$ (Trpc2 ${ }^{-1-}$; stock \#021208, The Jackson Laboratory; RRID:IMSR_JAX:021208; Stowers et

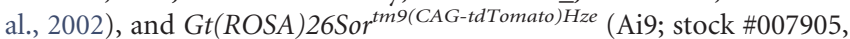
The Jackson Laboratory; RRID:IMSR_JAX:007905; Madisen et al., 2010) mice were obtained from The Jackson Laboratory. A total of 119 mice were used in this study.

Experimental design. Resident male mice were individually housed on corncob bedding, without cage changes, for 1 week before the experiment. All behavior occurred during the dark phase [zeitgeber time 20 (ZT20) to ZT24] in a dimly lit room to facilitate video recording. After a 10 min habituation period, a BALB/cJ male intruder mouse was introduced to the resident cage for a $10 \mathrm{~min}$ encounter. To test the response to soiled bedding alone, a small Petri dish was filled with bedding from a cage of four BALB/CJ males that had gone without cage changes for 1 week. This Petri dish was introduced into the resident's cage for $10 \mathrm{~min}$ instead of an intruder animal. Following behavior, imaging and electrophysiological experiments were performed as described below in detail.

Live slice preparation. Animals were anesthetized with isoflurane and decapitated $3 \mathrm{~h}$ after the resident-intruder paradigm was completed, unless otherwise specified. Brains were dissected, and $400 \mu \mathrm{m}$ parasagittal sections of the AOB were prepared using a Leica VT1200 vibrating microtome in ice-cold, oxygenated artificial CSF (ACSF). The ACSF contained $125 \mathrm{~mm} \mathrm{NaCl}, 2.5 \mathrm{~mm} \mathrm{KCl}, 2 \mathrm{~mm} \mathrm{CaCl}, 1 \mathrm{~mm} \mathrm{MgCl}_{2}, 25 \mathrm{~mm}$ $\mathrm{NaHCO}_{3}, 1.25 \mathrm{~mm} \mathrm{NaH}_{2} \mathrm{PO}_{4}, 25 \mathrm{~mm}$ glucose, $3 \mathrm{~mm}$ myoinositol, $2 \mathrm{~mm}$ Na-pyruvate, and $0.4 \mathrm{~mm} \mathrm{Na}$-ascorbate, with an additional $9 \mathrm{~mm} \mathrm{MgCl}_{2}$ in the slicing buffer. After slicing, the slices were kept in a recovery chamber at room temperature $\left(22^{\circ} \mathrm{C}\right)$ containing ACSF with $0.5 \mathrm{~mm}$ kynurenic acid to prevent potential glutamate excitotoxicity during the recovery/ holding period. Just before recordings, slices were transferred to a slice chamber (Warner Instruments) mounted on a fluorescence and differential interference contrast imaging-equipped upright microscope (Model FN1, Nikon). Oxygenated ACSF was superfused via a peristaltic pump (Gilson) at a rate of $1-2 \mathrm{ml} / \mathrm{min}$ throughout. Slice temperature was maintained at $32-$ $33^{\circ} \mathrm{C}$ via in-line and chamber heaters (Warner Instruments).

Two-photon imaging and image analysis. Image stacks up to $200 \mu \mathrm{m}$ deep were acquired using an excitation wavelength of $890 \mathrm{~nm}$ and a $40 \times$ [1.0 numerical aperture (NA)] water-immersion objective (Olympus). Images were denoised using a 3D median filter and deconvolved using a model point spread function in ImageJ (RRID:SCR_003070). Fluorescent cells were counted using a 3D object-counting add-on (Bolte and Cordelières, 2006). Cell counts were normalized to the volume of the cell layer of interest. $I_{\mathrm{Arc}}$ sum was computed as follows:

$$
I_{\mathrm{Arc}} \operatorname{sum}=\frac{\sum_{i=1}^{n} I_{\operatorname{Arc}(i)}}{x \mu m^{3}}
$$

where $I_{\operatorname{Arc}(i)}$ is the normalized brightness of each cell $\left(I_{\operatorname{Arc}(i)}=\frac{B_{i}}{K}\right) \cdot B_{i}$ is the mean pixel intensity within cellular region of interest $I, K$ is the mean pixel intensity within the internal cellular layer (ICL) but outside cellular regions of interest, and $x$ is the total volume within the imaged portion of the ICL. This metric combines the relative brightness of all identified cells and is normalized by the imaged volume to facilitate comparisons across experimental preparations.

Immunohistochemistry. Following behavior, animals were briefly anesthetized with inhaled isoflurane, then injected with a ketamine/xylazine cocktail (120 mg/kg ketamine $/ 16 \mathrm{mg} / \mathrm{kg}$ xylazine dose) and transcardially perfused with $0.01 \mathrm{M}$ PBS followed by $4 \%$ paraformaldehyde (PFA) in PBS. Brains were postfixed in 4\% PFA in PBS overnight. Brains were then cryoprotected overnight in PBS containing 25\% sucrose, embedded in OCT compound (TissueTek), and flash frozen. The $30 \mu \mathrm{m}$ sections were prepared using a Leica CM3050 S cryostat and were processed free floating. Sections were rinsed four times in $0.01 \mathrm{M}$ PBS, incubated in $0.1 \%$ 
A

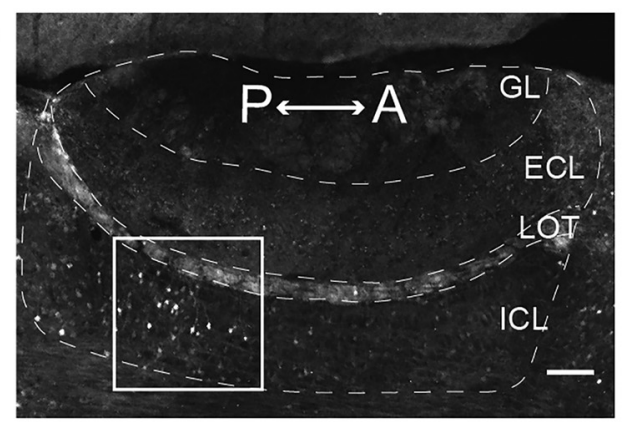

C

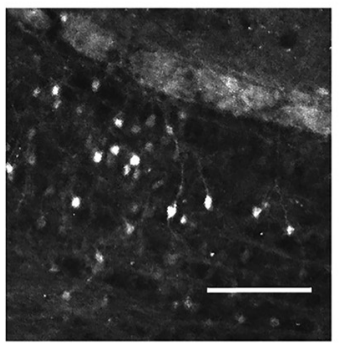

D

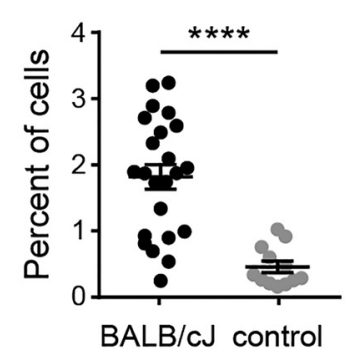

B

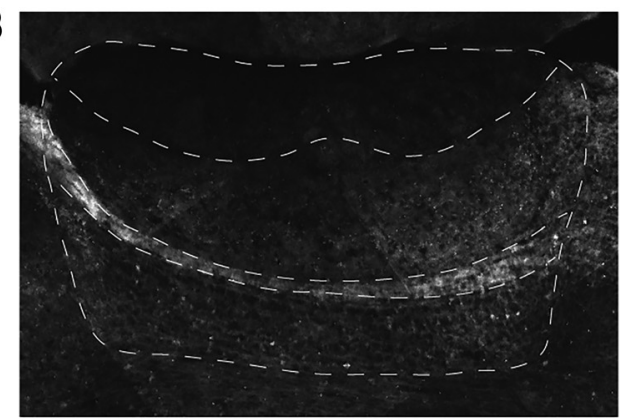

E

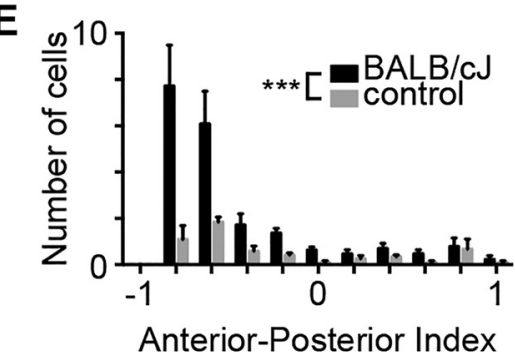

Figure 1. Exposing resident males to novel male intruders results in upregulation Arc protein expression in $A 0 B$ IGCs. $A$, Parasagittal section through the $A 0 B$ of a $C 57 B L / 6 \mathrm{~J}$ male resident 90 min after being exposed to a BALB/d male intruder. Immunofluorescence indicates Arc protein expression. Scale bar, $100 \mu \mathrm{m} . n=6$ animals, 23 sections. GL, Glomerular layer; $\mathrm{LOT}$, lateral olfactory tract. $B$, AOB section from a control resident that was not exposed to an intruder. $n=3$ animals, 12 sections. $C$, Enhanced view of IGCs in the boxed in area in $A$. D, Percentage of all cells expressing somatic Arc protein. Wilcoxon-MannWhitney test, ${ }^{* * * *} p<0.0001$. Scale bar, $100 \mu \mathrm{m}$. $\boldsymbol{E}$, Normalized anterior-posterior position of Arc-expressing cells in the ICL. Wilcoxon-Mann-Whitney test, ${ }^{* * *} p<0.001$.

Triton X-100 in PBS for $2 \mathrm{~h}$, rinsed three times, incubated in 10\% goat serum in PBS for $2 \mathrm{~h}$, and incubated in primary antibody in primary block $\left(0.1 \%\right.$ Triton $\mathrm{X}-100,10 \%$ goat serum in PBS) overnight at $4^{\circ} \mathrm{C}$. Sections were then rinsed three times in PBS and incubated in secondary antibody in secondary block ( $0.1 \%$ Triton X-100, 5\% goat serum) for $2 \mathrm{~h}$. Sections were rinsed three times, incubated in $500 \mathrm{~nm}$ DAPI in PBS, and rinsed three additional times. Sections were then mounted on slides in Fluoromount-G Mounting Medium (SouthernBiotech). Anti-Arc primary antibody specificity (rabbit polyclonal antibody; catalog \#156003, Synaptic Systems; RRID:AB_887694) was verified using $\mathrm{Arc}^{-1-}$ mice and was used at 1:1000. Anti-GFP primary (chicken polyclonal antibody; catalog \#ab13970, Abcam; RRID:AB_300798) was used at 1:500. Goat anti-rabbit AF633 (catalog \#A21070, Invitrogen; RRID:AB_2535731) and goat anti-chicken AF488 (catalog \#A11039, Invitrogen; RRID: AB_142924) were both used at 1:2000 dilution.

Biocytin amplification of filled neurons was achieved using streptavidin-Alexa Fluor 568 (catalog \#S11226, Thermo Fisher; RRID: AB_2315774). Slices were washed in PBS three times for $30 \mathrm{~min}$ each. Slices were then incubated in a blocking solution containing $0.5 \%$ Triton $\mathrm{X}-100$ and $10 \%$ goat serum in PBS for $2 \mathrm{~h}$, followed by the same blocking solution containing streptavidin-AF568 at $0.01 \mathrm{mg} / \mathrm{ml}$ for $4 \mathrm{~h}$. Slices were then rinsed three times for $30 \mathrm{~min}$ each and mounted on slides in Fluoromount-G Mounting Medium.

For the experiments seen in Figures 2 and 5, immunostained sections were imaged with a $40 \times(1.3 \mathrm{NA})$ oil-immersion objective on an LSM 510 Inverted Confocal Microscope (Zeiss). For the experiments in Figure 1 , immunostained sections were imaged with a Zeiss Axioscan.Z1 microscope using a $20 \times(0.8 \mathrm{NA})$ air-objective. Cells were counted manually using ImageJ by a scorer blinded to the experimental condition. The anterior-posterior index was calculated using custom MATLAB software. Spines were counted, and morphological analysis performed using the Simple Neuron Tracer plugin for ImageJ (Longair et al., 2011) by a scorer blinded to experimental conditions. Spines were counted on the $100 \mu \mathrm{m}$ of primary dendrite in the external cellular layer (ECL) starting at the edge of the lateral olfactory tract.

Electrophysiology. Whole-cell patch-clamp recordings were made on destabilized EGFP with a $4 \mathrm{~h}$ half-life-positive $\left(\mathrm{d}_{4} \mathrm{EGFP}^{+}\right)$and d4EGFP ${ }^{-}$IGCs during a window spanning $4-8 \mathrm{~h}$ following behavior. Thin wall borosilicate glass electrodes with a tip resistance between 4 and $12 \mathrm{M} \Omega$ were filled with internal solution containing the following (in mM): $115 \mathrm{~K}$-gluconate, 20
$\mathrm{KCl}, 10$ HEPES, 2 EGTA, $2 \mathrm{MgATP}, 0.3 \mathrm{Na}_{2} \mathrm{GTP}, 10 \mathrm{Na}$ phosphocreatine at $\mathrm{pH}$ 7.37. All recordings were amplified using a MultiClamp 700B amplifier (Molecular Devices) at $20 \mathrm{kHz}$ and were digitized by a DigiData 1440 analog-digital converter controlled via pClamp 10.5 software (Molecular Devices; RRID:SCR_011323). Data were analyzed by Clampex 10.5 (Molecular Devices) and custom software written in MATLAB.

For glomerular stimulation experiments, a theta glass-stimulating electrode was placed in the glomerular layer while recordings were made from IGCs. A series of $0.3 \mathrm{~ms}$ single pulses was used to construct inputoutput curves (Stimulus Isolator A365RC, World Precision Instruments), and the stimulation intensity for $20 \mathrm{~Hz}$ trains was the highest subsaturating value from the input-output analysis. One $\mathrm{d} 4 \mathrm{EGFP}^{+}$and one $\mathrm{d}_{4 \mathrm{EGFP}^{-}}$neuron were recorded per slice (one at a time). The $\mathrm{d} 4 \mathrm{EGFP}^{+}$neuron was recorded first in 6 of 10 pairs. Input-output curves were generated for each neuron, but the stimulation intensity used for both was chosen based on the first neuron recorded. Before MC recordings, we confirmed that stimulus conditions effectively recruited IGCs through direct IGC patch-clamp recordings (23 of 24 recordings).

For miniature EPSC (mEPSC) recordings, 5 min of baseline activity was recorded, then $1 \mu \mathrm{M}$ TTX was washed on for $5 \mathrm{~min}$, and $5 \mathrm{~min}$ of postdrug activity was recorded. Biocytin $(3 \mathrm{mg} / \mathrm{ml})$ and/or Alexa Fluor $568(166 \mu \mathrm{M})$ was added to the internal solution to visualize dendritic arbors and spines. After filling, slices were fixed in 4\% PFA in PBS for $1 \mathrm{~h}$ and then stored in PBS at $4^{\circ} \mathrm{C}$.

To assess intrinsic electrophysiological features, we subjected patched $\mathrm{AOB}$ neurons to a series of current-clamp and voltage-clamp challenges. Immediately after achieving the whole-cell configuration, the resting membrane potential $\left(V_{\text {rest }}\right)$ of each cell was measured in current-clamp mode. To standardize measurements across cells with different $V_{\text {rest }}$, we injected steady-state currents to maintain the membrane potential $\left(V_{\mathrm{m}}\right)$ of each cell between -70 and $-75 \mathrm{mV}$. Based on initial measurements of input resistance $\left(R_{\text {input }}\right)$, we empirically determined the amplitude of hyperpolarizing current that adjusted $V_{\mathrm{m}}$ by $-50 \mathrm{mV}$ (to approximately $-125 \mathrm{mV}$ ). After determining this initial current injection amplitude, we generated a cell-specific 10-sweep Clampex protocol that applied increasingly depolarizing $0.5 \mathrm{~s}$ square current pulses, starting with the initial injection amplitude. For example, if the initial current injection was determined to be $-100 \mathrm{pA}$, the 10 -sweep protocol would have current injection increments of $+20 \mathrm{pA}$ (i.e., $-100,-80,-60, \ldots+80 \mathrm{pA}$ ). If the initial depolarization was determined to be $-125 \mathrm{pA}$, the protocol 
Table 1. Parameters used for multidimensional analysis

\begin{tabular}{|c|c|c|c|c|}
\hline Shorthand & Description & Mode & Method & Reference \\
\hline $\begin{array}{l}V_{\text {rest }} \\
C_{\mathrm{m}} \\
R_{\mathrm{m}}\end{array}$ & $\begin{array}{l}\text { Resting membrane potential } \\
\text { Membrane capacitance } \\
\text { Input resistance }\end{array}$ & IClamp & Direct measurement & N/A \\
\hline$N_{\text {comps }}$ & Number of model compartments & I Clamp & See reference & Golowasch et al., 2009 \\
\hline Ih_sag & Hyperpolarization-induced depolarizing potential & IClamp & $I_{H, \text { sag }}=V_{\text {init }}-V_{\text {ss }}$ & $\mathrm{N} / \mathrm{A}$ \\
\hline Ih_current & Hyperpolarization-induced depolarizing current & V Clamp & $I_{H, \text { curr }}=I_{\text {init }}-I_{\mathrm{ss}}$ & N/A \\
\hline EPSC_freq & Mean spontaneous EPSC frequency & VClamp & & \\
\hline EPSC_amp & Mean spontaneous EPSC amplitude & VClamp & Direct measurement after waveform sorting & Hendrickson et al., 2008 \\
\hline EPSC_tau & Mean spontaneous EPSC decay constant & V Clamp & Least-squares exponential decay & $\mathrm{N} / \mathrm{A}$ \\
\hline S_freq_1 & Spiking frequency: Lv. 1 & IClamp & Direct measurement & N/A \\
\hline S_freq_2 & Spiking frequency: Lv. 2 & IClamp & Direct measurement & N/A \\
\hline S_freq_3 & Spiking frequency: Lv. 3 & I Clamp & Direct measurement & N/A \\
\hline S_freq_4 & Spiking frequency: Lv. 4 & I Clamp & Direct measurement & N/A \\
\hline S1_slope & Initial action potential rising slope & IClamp & Initial spike derivative peak & \\
\hline S1_thresh & Initial action potential threshold & I Clamp & $V_{m}$ at $10 \%$ of initial spike derivative & Meeks et al., 2005 \\
\hline S_accom_1 & Spike rate accommodation: Lv. 1 & I Clamp & & \\
\hline S_accom_2 & Spike rate accommodation: Lv. 2 & IClamp & & \\
\hline S_accom_3 & Spike rate accommodation: Lv. 3 & IClamp & & \\
\hline S_accom_4 & Spike rate accommodation: Lv. 4 & IClamp & $\frac{S_{\text {init }}-S_{\text {final }}}{S_{\text {init }}+S_{\text {final }}}$ & N/A \\
\hline Na_curr_1 & Voltage-gated sodium current amplitude: Lv. 1 & V Clamp & Direct measurement & N/A \\
\hline Na_curr_2 & Voltage-gated sodium current amplitude: Lv. 2 & V Clamp & Direct measurement & N/A \\
\hline Na_curr_3 & Voltage-gated sodium current amplitude: Lv. 3 & V Clamp & Direct measurement & N/A \\
\hline Na_curr_4 & Voltage-gated sodium current amplitude: Lv. 4 & V Clamp & Direct measurement & N/A \\
\hline Na_curr_5 & Voltage-gated sodium current amplitude: Lv. 5 & V Clamp & Direct measurement & $\mathrm{N} / \mathrm{A}$ \\
\hline K_curr_max & Voltage-gated potassium current: maximum & V Clamp & Direct measurement & $\mathrm{N} / \mathrm{A}$ \\
\hline K_curr_diff & Noninactivating voltage-gated potassium current & V Clamp & Direct measurement & N/A \\
\hline
\end{tabular}

N/A, Not applicable; Lv., level; V Clamp, voltage clamp; I Clamp, current clamp.

would include increments of, for example, $+25 \mathrm{pA}$. This strategy allowed us to objectively challenge cells with widely varying $V_{\text {rest }}$ and $R_{\text {input }}$ values. In voltage clamp, cells were initially held at $-70 \mathrm{mV}$, and a series of 12 voltage command steps ( $0.5 \mathrm{~s}$ in duration) were applied that spanned -100 to $+10 \mathrm{mV}$.

For each cell, both current-clamp and voltage-clamp protocols were applied up to four times, and all reported quantities represent the mean responses across repeated trials. Twenty-six specific intrinsic parameters were extracted from each cell using custom software written in MATLAB. A description of the parameters seen in Figure $6 A$ and the formulas used to calculate them is presented in Table 1. The hyperpolarization-activated cation $\left(I_{\mathrm{H}}\right)$ current ratio (see Fig. $6 G$ ) was calculated using the following formula:

$$
\frac{I_{\text {init }}-I_{\mathrm{ss}}}{I_{\text {init }}}
$$

where $I_{\text {init }}$ is the mean initial current (measured between 10 and $160 \mathrm{~ms}$ following the voltage pulse) and $I_{\mathrm{SS}}$ is the mean steady-state current (measured between 420 and $470 \mathrm{~ms}$ after the voltage pulse) generated by a voltage command step from -70 to $-100 \mathrm{mV}$. EPSCs were automatically detected and later separated from noise using a custom computerassisted waveform-based event-sorting program written in MATLAB (Hendrickson et al., 2008). EPSC decay was measured by calculating the best fit exponentially decaying line for the decay period of the EPSC. Initial action potential rising slope was calculated by measuring the peak of the first derivative of voltage with respect to time (dV/dt). Threshold was defined as $V_{\mathrm{m}}$ at the time the $\mathrm{dV} / \mathrm{dt}$ voltage reached $10 \%$ of its peak value (similar to Meeks et al., 2005). Membrane capacitance and input resistance were calculated according to current clamp-based multicompartmental algorithms (Golowasch et al., 2009). Briefly, the voltage response of each cell to a hyperpolarizing current step was fit with a series of multiexponential curves, and the best fit was determined by identifying the solution with the lowest value of the Bayesian Information Criterion (to avoid overfitting).

Statistical Analysis. Unless otherwise indicated, comparisons between two groups were made using the nonparametric Wilcoxon-MannWhitney test. Comparisons involving multiple experimental groups were made using one-way ANOVA. Repeated-measures ANOVA was used for
$20 \mathrm{~Hz}$ glomerular stimulation experiments. Statistical significance threshold was set at $p<0.05$ for all comparisons.

\section{Results}

\section{Arc expression is upregulated in posterior AOB IGCs following resident-intruder encounters}

Arc is expressed in IGCs in rodents shortly after mating, an AOSmediated behavior that induces pheromonal memory formation in females (Bruce and Parrott, 1960; Brennan et al., 1995; Matsuoka et al., 2002a, 2003). If experience-dependent plasticity in the $\mathrm{AOB}$ is a more general response to chemosensory social events, we hypothesized that the social chemosensory encounters associated with male-male territorial aggression, which is AOS mediated, would induce AOB plasticity. We used the residentintruder paradigm, which is known to encourage AOS-dependent territorial aggression between males, as our behavioral challenge (Maruniak et al., 1986; Stowers et al., 2002). Adult male wild-type C57BL/6J residents were housed individually for 1 week and then exposed to adult male BALB/cJ intruders for $10 \mathrm{~min}$. Arc protein expression was significantly increased $90 \mathrm{~min}$ after the behavior in AOB IGCs of resident males compared with controls (WilcoxonMann-Whitney test, $p<0.0001$; Fig. $1 A-D)$. Previous studies indicated that male-male resident-intruder encounters increase Fos expression in the pAOB, which is selectively innervated by vomeronasal sensory neurons (VSNs) that express members of the V2R subfamily of vomeronasal receptors (Belluscio et al., 1999; Kumar et al., 1999; Rodriguez et al., 1999; Chamero et al., 2007). Consistent with these results, Arc protein expression after the resident-intruder paradigm was selectively upregulated in pAOB IGCs (Wilcoxon-Mann-Whitney test, $p<0.001$; Fig. $1 E)$. These initial results show that Arc expression in IGCs following resident-intruder behavior is similar to Arc expression following mating behavior and suggest that Arc expression oc- 
curs in an interneuron population that might increase MC inhibition after resident-intruder encounters.

\section{Arc-d4EGFP-BAC tools mark}

$A r c$-expressing IGCs in a time- and chemosignal-dependent manner To identify Arc-expressing IGCs in live tissue, we used Arc-d4EGFP-BAC reporter mice (Grinevich et al., 2009). In these mice, d4EGFP is expressed under the control of the Arc promoter on a bacterial artificial chromosome, leaving endogenous Arc unperturbed. To assess the Arc-d4EGFPBAC reporter, we used Arc-d4EGFP-BAC male mice as residents in the resident-intruder paradigm. We sacrificed animals at various time points following behavior (Fig. 2A) and compared Arc protein and d4EGFP immunostaining levels to controls (no intruder, BALB/cJ male soiled bedding only; Fig. $2 A-D$ ). Arc protein expression began rising by $30 \mathrm{~min}$ postbehavior, peaked $1-2 \mathrm{~h}$ postbehavior and returned to baseline by $4 \mathrm{~h}$ postbehavior (one-way ANOVA, $F_{(7,11)}=18.64, p<$ $0.0001 ; n=1-2$ mice and $2-3$ sections/ condition; 11 mice and 19 sections overall; Fig. 2A,C). d4EGFP levels increased significantly by $1 \mathrm{~h}$ postbehavior and remained elevated at $4 \mathrm{~h}$ postbehavior (oneway ANOVA, $F_{(7,11)}=13.07, p=0.0002$; Fig. $2 A, D)$. We observed strong colocalization between the Arc protein and d4EGFP signals, while some cells showed d4EGFP signal but no Arc protein in the cell soma. This effect could be explained by the fact that Arc protein is often localized to the dendrites (Shepherd and Bear, 2011) and that low levels of d4EGFP expression (indicating low-level Arc transcription) were boosted by immunostaining.

Because d4EGFP immunostaining boosts very weak signals, we wanted to test whether d4EGFP expression alone was sufficient to identify Arc-expressing cells in living tissue. Live two-photon imaging of acute AOB slices from Arc-d4EGFP$\mathrm{BAC}$ residents revealed robust $\mathrm{d} 4 \mathrm{EGFP}$ expression starting at $3 \mathrm{~h}$ postbehavior and remaining strong until $6 \mathrm{~h}$ postbehavior (Fig. 2E). Thus, unamplified d4EGFP signals lag behind the immunostaining time course, which is likely due to differences in antibody-amplified versus native d4EGFP signals. Importantly, the time window including the strongest behaviorally driven d4EGFP expression was well aligned with the time course of acute slice electrophysiological experiments, making the Arc-d4EGFP-BAC mice a strong tool for investigating the physiological properties of Arc-expressing IGCs.

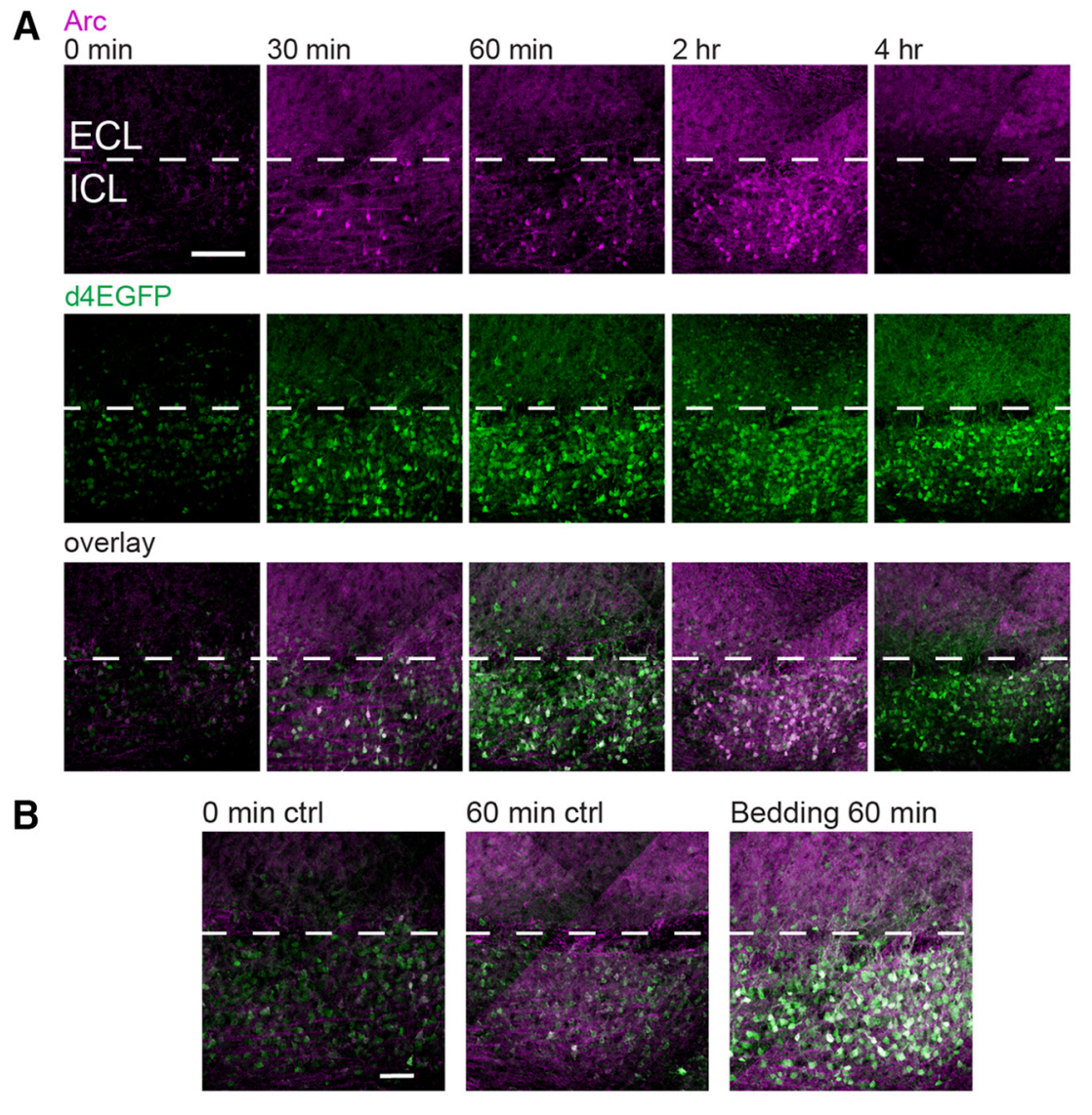

C

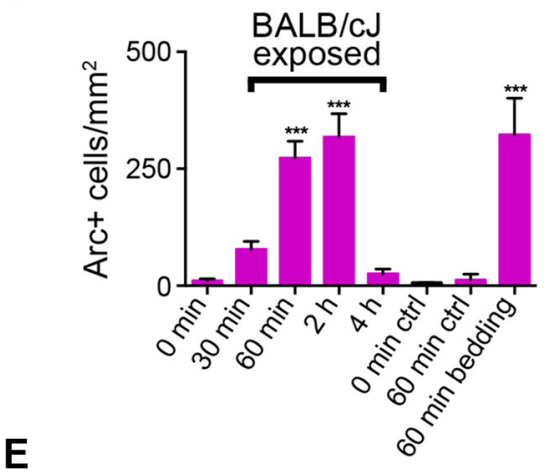

D

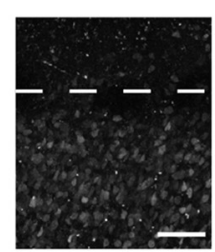

$2 \mathrm{~h}$

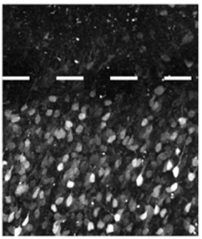

$3 \mathrm{~h}$

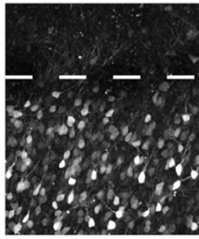

$4 \mathrm{~h}$

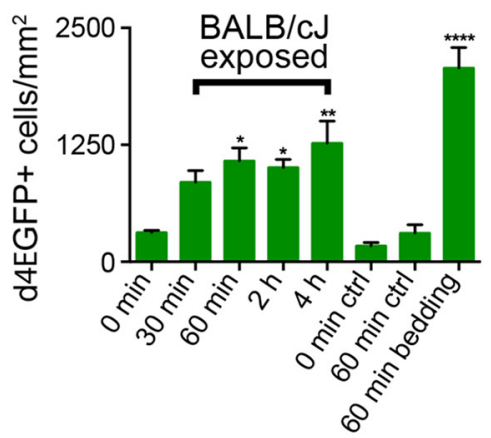

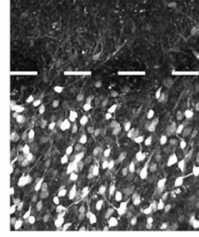

$5 \mathrm{~h}$

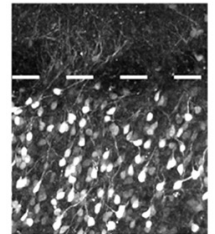

$6 \mathrm{~h}$
Figure 2. Arc protein expression peaks $2 \mathrm{~h}$ after behavior and overlaps with d4EGFP expression in Arc-d4EGFP-BAC mice. $A$, Parasagittal AOB sections from resident mice perfused $0,30,60,120$, or 240 min after behavior, stained for both Arc protein and d4EGFP. The ICL is indicated by white dotted lines, and posterior AOB is shown. Scale bar, $100 \mu \mathrm{m}$. $\boldsymbol{B}$, Arc protein and d4EGFP expression in negative control mice that were perfused after 0 or $60 \mathrm{~min}$ in the behavioral setup but were not exposed to a $B A L B / C$ intruder (left two panels). Arc protein and d4EGFP expression in a resident mouse that was exposed to soiled BALB/cJ bedding only in the behavioral setup then was perfused $60 \mathrm{~min}$ later. Scale bar, $50 \mu \mathrm{m}$. C, Quantification of Arc immunostaining across conditions. One-way ANOVA, $F_{(7,11)}=18.64, p<0.0001$. D, Quantification of d4EGFP immunostaining across conditions. Oneway ANOVA, $F_{(7,11)}=13.07, p=0.0002$. For $C$ and $\boldsymbol{D}$ : ${ }^{*} p<0.05$, ${ }^{* *} p<0.01,{ }^{* *} p<0.001$, and ${ }^{* * *} p<0.0001$, compared with the 0 min controls ( 19 sections across 11 mice; ANOVA corrected for multiple comparisons using Dunnett's method). $\boldsymbol{E}$, Time course of d4EGFP expression in a single acute live slice visualized using two-photon microscopy. Each image is a maximum z-projection of a $200 \mu \mathrm{m}$ slice. Dissection occurred $1 \mathrm{~h}$ after behavior. Scale bar, $100 \mu \mathrm{m}$. ctrl, Control. 

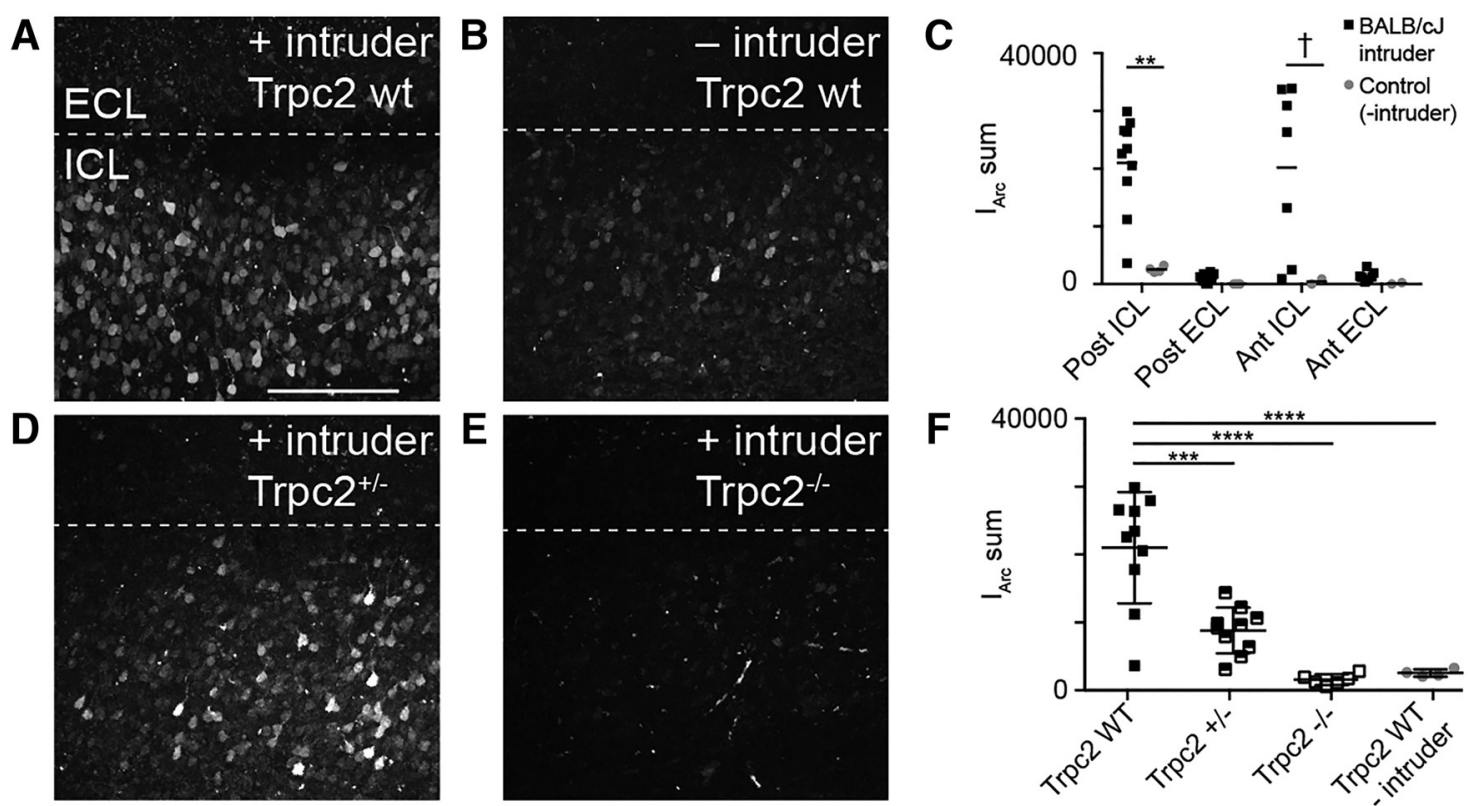

Figure 3. Arc expression is not upregulated after the resident-intruder assay in $\operatorname{Trpc} 2^{-1-}$ mice. A, Maximum z-projection of an acute AOB slice taken from an Arc-d4EGFP-BAC, Trpc $2^{+/+}$ resident. Posterior $A 0 B$ is shown. Images were taken $4 \mathrm{~h}$ after exposure to a BALB/CJ intruder. Scale bar, $200 \mu m$. $B$, Representative $z$-projection taken from a control resident that was not exposed to an intruder. C, Quantification of summed fluorescence intensity across d4EGFP-expressing cells $\left(I_{\text {Arc }}\right.$ sum). Significance in each region was determined using the Wilcoxon-Mann-Whitney test: ${ }^{* *} p<0.01 ; \dagger p<0.1$. Posterior ICL: $n=9$ mice, 10 slices (experimental), $n=4$ mice, 4 slices (control); posterior ECL: $n=9$ mice, 10 slices (experimental), $n=3$ mice, 3 slices (control); anterior ICL/ECL: $n=6$ mice, 7 slices (experimental) $n=2$ mice, 2 slices (control). $\boldsymbol{D}$, Representative $z$-projection taken from a Trpc ${ }^{+1-}$ Arc-d4EGFP-BAC male resident. E, Representative $z$-projection

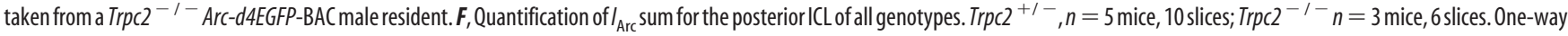
ANOVA, $F_{(3,26)}=22.75, p<0.0001 .{ }^{* * *} p<0.001,{ }^{* * * *} p<0.0001$ for indicated pairs (corrected for multiple comparisons using Tukey's method).

Before we tested Arc-expressing IGC physiology, we wanted to determine whether d4EGFP expression required AOS sensory activation. This was important because different salient behaviors can activate centrifugal input into the entire olfactory bulb (Shipley et al., 1985; Brennan et al., 1990; Nunez-Parra et al., 2013; Rothermel et al., 2014; Oettl et al., 2016). Previous studies of AOB IEG expression indicated that chemosensory stimulation alone (soiled bedding) is sufficient to induce Arc expression and that social interaction increases this effect (Matsuoka et al., 2002b). Having confirmed that AOS chemosensory stimulation alone was sufficient to induce robust Arc expression (Fig. $2 B-D$ ), we wanted to next determine whether AOS activation was necessary for Arc expression. To accomplish this, we backcrossed Arcd4EGFP-BAC reporter mice into a $\operatorname{Tr} p c 2^{-1-}$ background. $\operatorname{Tr} p c 2$, which is expressed in all vomeronasal sensory neurons and a small percentage of main olfactory sensory neurons, is required for proper chemosensory transduction (Omura and Mombaerts, 2014). Thus, $\operatorname{Trp} c 2^{-1-}$ mice have severely disrupted vomeronasal chemosensory transduction and profound changes to AOSmediated behaviors while retaining most main olfactory function (Stowers et al., 2002; Kimchi et al., 2007; Papes et al., 2010). We introduced Arc-d4EGFP-BAC, $\operatorname{Trpc} 2^{-1-}$ resident males to $\mathrm{BALB} / \mathrm{cJ}$ male intruders and imaged acutely prepared live $\mathrm{AOB}$ slices using two-photon microscopy $4 \mathrm{~h}$ postbehavior, a time of robust d4EGFP expression after resident-intruder behaviors (Fig. 3). We quantified d4EGFP expression in the posterior ICL for $\operatorname{Tr} p c 2^{+1+}, \operatorname{Tr} p c 2^{+/-}$, and $\operatorname{Tr} p c 2^{-1-}$ animals exposed to intruders, as well as $\operatorname{Trp} c 2^{+/+}$residents that were left alone in an empty cage (no intruder) for $10 \mathrm{~min}$ (Fig. $3 A-F$ ). Compared with the $\operatorname{Trp} c 2$ wild-type mice, all other groups showed significantly reduced d4EGFP expression (one-way ANOVA: $F_{(3,26)}=22.75$, $p<0.0001$; Fig. $3 F$ ). This reduction occurred despite the fact that $\mathrm{Trpc}^{-1-}$ animals do not display deficits in olfactory social investi- gation (Stowers et al., 2002). Total d4EGFP intensity in $\operatorname{Trpc} 2^{-1-}$ animals exposed to intruders matched that of $\operatorname{Trpc} 2^{+1+}$ animals left alone in an empty cage, indicating that sensory input from VSNs is necessary for the elevated Arc expression in AOB IGCs (Fig. $3 F$ ). These results show that $A r c-d 4 E G F P-B A C$ reporter mice label Arc-expressing IGCs in living AOB tissue and also show that VSN activation is both necessary and sufficient to induce AOB Arc expression after resident-intruder encounters.

\section{Arc-expressing IGCs respond strongly to glomerular stimulation}

Previous work showed experience-dependent increases in inhibitory tone in the AOB following salient social behavior, suggesting that IGCs increase their inhibitory influence on MC output (Brennan et al., 1990, 1995). If the IGCs expressing Arc after social chemosensory interactions contribute to AOB experiencedependent plasticity, we hypothesized that Arc-expressing IGCs would respond differently to AOB sensory input than nonexpressing IGCs. To test this hypothesis, we made targeted wholecell patch-clamp recordings from $\operatorname{Arc}$-expressing $\left(\mathrm{d} 4 \mathrm{EGFP}^{+}\right)$ and nonexpressing $\left(\mathrm{d}_{4} \mathrm{EGFP}^{-}\right)$IGCs in acute slices $4-8 \mathrm{~h}$ after resident-intruder experiments (Fig. 4). To simulate sensory activity, we electrically stimulated VSN fibers in the AOB glomerular layer using theta-glass electrodes. Stimulating the glomerular layer induces glutamate release from VSN terminals and activates downstream MCs, which in turn activate IGCs at dendrodendritic synapses (Fig. 4A). Thus, IGC activation resulting from VSN terminal stimulation is a disynaptic effect. In voltage clamp, Arc-expressing IGCs showed increased single-pulse EPSC charge transfer and peak current amplitude compared with nonexpressing IGCs across stimulus intensities (paired, two-tailed Student's $t$ test, $p<0.05 ; n=10$ slices across seven mice; Fig. $4 B-F)$. ${\mathrm{d} 4 \mathrm{EGFP}^{+}}^{+}$IGCs were recorded first in 6 of 10 experiments, so we 
A

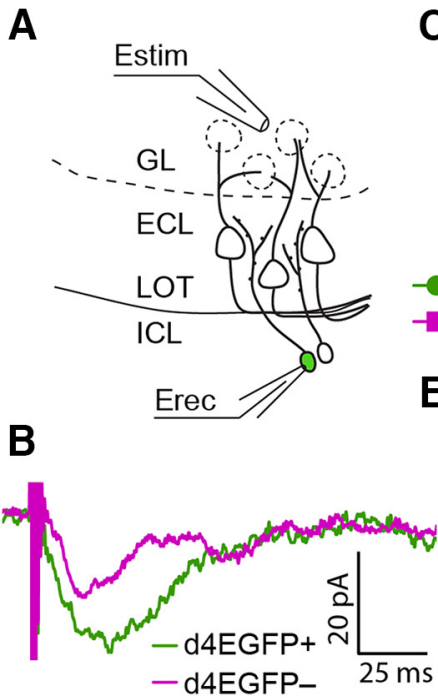

C

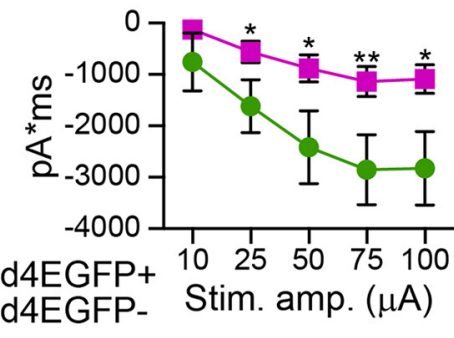

E

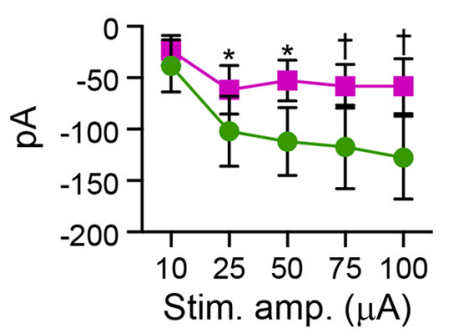

D

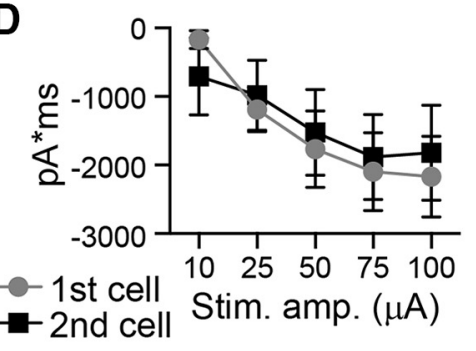

$\mathbf{F}$

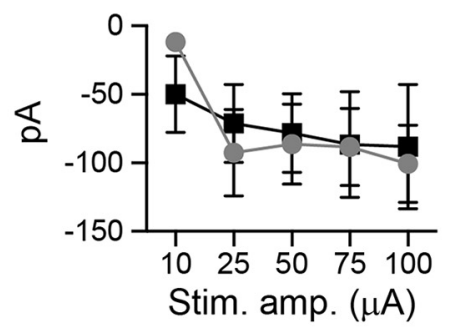

G

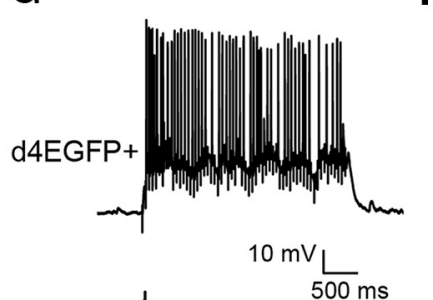

H

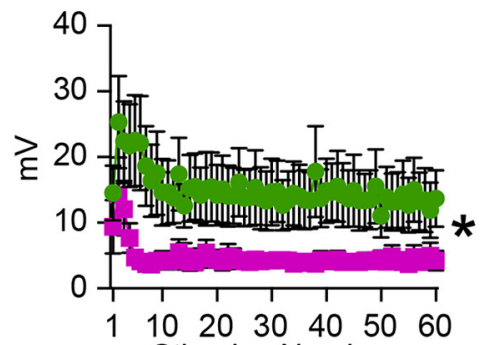

Stimulus Number
I

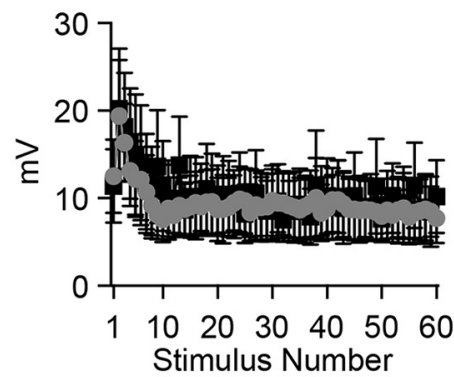

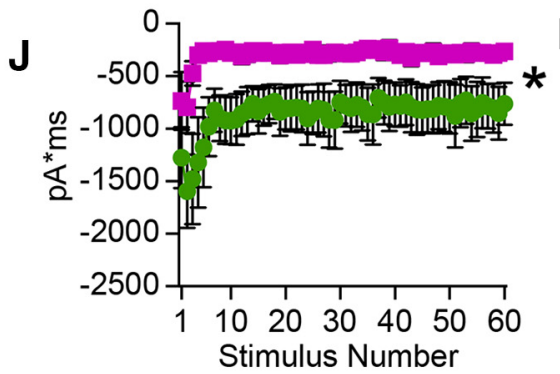

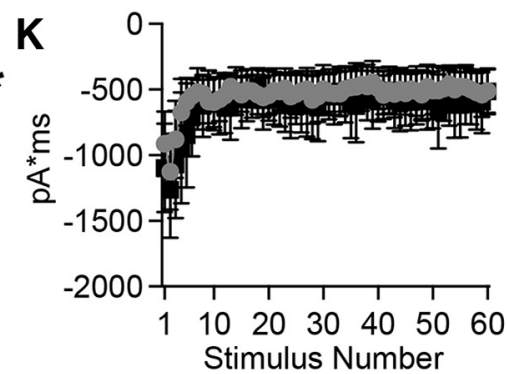

Figure 4. Arc-expressing IGCS show increased excitation by glomerular layer stimulation. A, Diagram illustrating experimental setup. Estim, Theta glass stimulating electrode; Erec, recording electrode. $\boldsymbol{B}$, Sample responses from a single, equal amplitude electrical stimulus from a d4EGFP ${ }^{+}$cell and a nearby d4EGFP ${ }^{-}$cell from the same slice. $\boldsymbol{C}$, Input- output curves showing charge transfer in response to a single stimulus pulse for d4EGFP ${ }^{+}$and d4EGFP ${ }^{-}$cells. Paired, two-tailed Student's $t$ test: ${ }^{*} p<0.05,{ }^{* *} p<0.01$. D, Same data as from $C$, grouped by the order in which the cells were recorded rather than d4EGFP expression. $E$, Input- output curves showing EPSC amplitude in response to a single pulse; data grouped by d4EGFP expression. Paired, two-tailed Student's $t$ test: $t p<0.1 ;{ }^{*} p<0.05$. $\boldsymbol{F}$, Same data from $\boldsymbol{E}$, grouped by the order in which cells were recorded. G, Sample traces from d4EGFP ${ }^{+}$and d4EGFP ${ }^{-}$IGCS responding to $3 \mathrm{~s}, 20 \mathrm{~Hz}$ stimulation. $\boldsymbol{H}$, Peak amplitude reached in response to each pulse of a $3 \mathrm{~s}, 20 \mathrm{~Hz}$ stimulus train. Repeated-measures ANOVA, main effect of group: $F_{(1,18)}=4.51, p=0.048 . \boldsymbol{I}$, Same data from $\boldsymbol{H}$, grouped by the recording order. Repeated-measures ANOVA, no main effect of group: $F_{(1,18)}=0.03, p=0.87$. J, Total charge transfer in response to each pulse of the $3 \mathrm{~s}, 20 \mathrm{~Hz}$ stimulus train. Repeated-measures ANOVA, main effect of group: $F_{(1,18)}=5.52, p=0.03$. $\boldsymbol{K}$, Same data from $J$, grouped by recording order. Repeated-measures ANOVA, no main effect of group: $F_{(1,18)}=0.07$, $p=0.79$. For all panels, $n=7$ mice, 10 slices, 10 pairs. Stim. amp., Stimulus amplitude.

investigated possible order effects by comparing these same responses based on the recording order (Fig. $4 D, F$ ). We found no differences in this comparison (paired, two-tailed Student's ttest, $p>0.05$ ), indicating that order effects cannot explain the increased excitability of d4EGFP ${ }^{+}$IGCs. To evaluate the physiological relevance of these responses, we approximated strong MC activation by delivering a $3 \mathrm{~s}, 20 \mathrm{~Hz}$ train of stimuli to glomerular layer (matching MC firing rates measured during direct chemosensory stimulation of the VNO; Meeks et al., 2010). In current clamp, d4EGFP ${ }^{+}$IGCs responded to trains with increased peak amplitudes, which were also sustained throughout the $3 \mathrm{~s}$ stimulus (repeated-measures ANOVA, main effect of group: $F_{(1,18)}=$ $4.51, p=0.048$; Fig. $4 G, H)$. This effect was eliminated when the same data were organized based on recording order (repeated- measures ANOVA, no main effect of group: $F_{(1,18)}=0.03, p=$ 0.87 ; Fig. $4 I)$. In voltage clamp, the same d4EGFP ${ }^{+}$IGCs responded to stimulus trains with significantly greater charge transfer than d4EGFP ${ }^{-}$IGCs and sustained this increase throughout the $3 \mathrm{~s}$ of stimulation (repeated-measures ANOVA, main effect of group: $F_{(1,18)}=5.52, p=0.03$; Fig. $\left.4 J\right)$. As before, this effect was not due to an effect of recording order (repeatedmeasures ANOVA, no main effect of group: $F_{(1,18)}=0.07, p=$ 0.79; Fig. $4 \mathrm{~K})$. These data indicate that Arc-expressing IGCs are more engaged by sensory input stimulation, which may reflect enhanced MC-IGC synaptic communication or increased IGC intrinsic excitability. These data also suggest that Arcexpressing IGCs may contribute to experience-dependent MC inhibition. 
A

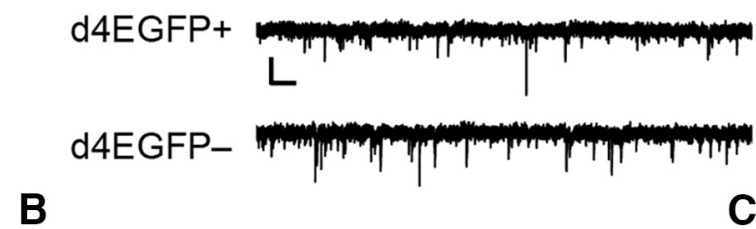

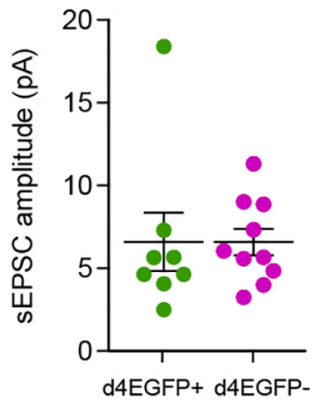

D

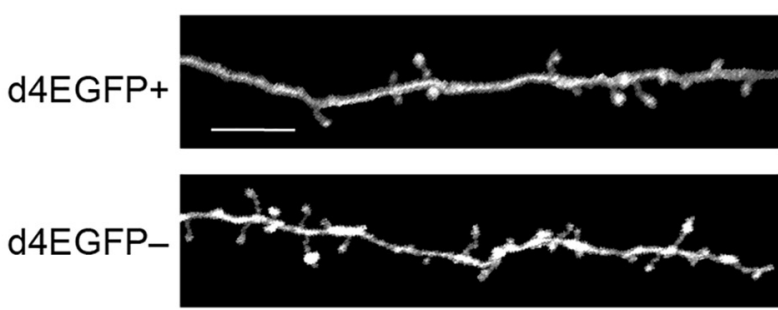

+ TTX

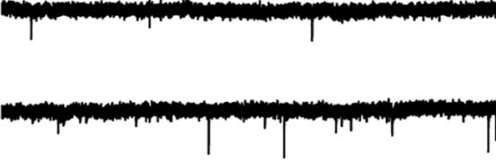

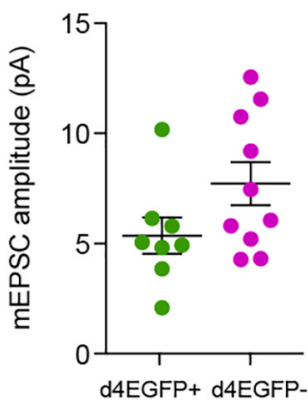

$\mathbf{E}$

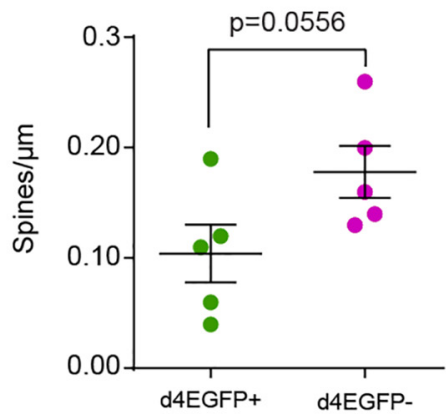

Figure 5. Arc-expressing IGCS do not display enhanced synaptic strength or number compared with nonexpressing IGCs. A, Sample sEPSC and mEPSC traces from d4EGFP ${ }^{+}$and d4EGFP ${ }^{-}$ neurons. Calibration: $10 \mathrm{pA}, 500 \mathrm{~ms}$. B, Spontaneous frequency and amplitude in d4EGFP ${ }^{+} \mathrm{IGCs}$. Significance determined using Wilcoxon-Mann-Whitney test (n.s., $\left.p>0.05\right)$. d4EGFP ${ }^{+}, n=8$; $\mathrm{d}_{\mathrm{AEGFP}}{ }^{-}, n=10 ; n$ mice $=10$. C, Mini-frequency and amplitude of d4EGFP ${ }^{+}$and d4EGFP ${ }^{-}$IGCs. Significance determined using Wilcoxon-Mann-Whitney test (n.s., $p>0.05$ ). d4EGFP ${ }^{+}$, $n=8 ; \mathrm{d}_{\mathrm{NEGFP}}{ }^{-} n=10 ; n=10$ mice. D, Representative images showing dendritic spines on d4EGFP ${ }^{+}$and d4EGFP ${ }^{-}$IGCS. Scale bar, $10 \mu \mathrm{m}$. E, Spines per micrometer for d4EGFP ${ }^{+}$and d4EGFP ${ }^{-}$ neurons. Significance determined using Wilcoxon-Mann-Whitney test. d4EGFP ${ }^{+}$cells, $n=5 ; \mathrm{d} 4 \mathrm{EGFP}^{-}$cells, $n=5 ; n=5$ mice.

\section{Arc-expressing IGCs do not possess increased synapse strength or density}

We hypothesized that the increased activation of Arc-expressing IGCs was due to a change in the number of MC-IGC synapses or a change in MC-IGC synaptic strength. To test these hypotheses, we recorded spontaneous EPSCs (sEPSCs) and mEPSCs from ${\mathrm{d} 4 \mathrm{EGFP}^{+} \text {and d4EGFP }}^{-}$IGCs (Fig. 5). Arc-expressing IGCs did not exhibit a significant difference in sEPSC or mEPSC amplitude or frequency (Wilcoxon-Mann-Whitney test, $p>0.05$; Fig. $5 A-C$ ). In these experiments, biocytin was included in the recording pipette to allow post hoc analysis of dendrite morphology and dendritic spine density. Analysis of IGC dendrites showed a trend toward slightly lower spine densities in Arc-expressing IGCs compared with nonexpressing IGCs (Wilcoxon-Mann-Whitney test, $p=0.0556$; Fig. $5 D, E$ ). Similarly, there were no differences in average dendritic branch length $\left(\mathrm{d}_{4} \mathrm{EGFP}^{+}: 485.3 \pm 115.7\right.$ $\mu \mathrm{m}, n=6$; d4EGFP ${ }^{-}: 365.5 \pm 57.2 \mu \mathrm{m}, n=8$; WilcoxonMann-Whitney test, $p=0.57$ ), maximum dendritic branch length $\left(\mathrm{d} 4 \mathrm{EGFP}^{+}: 1813 \pm 149.4 \mu \mathrm{m}, n=6\right.$ d4EGFP $^{-}: 1548 \pm$ $231.4 \mu \mathrm{m}, n=8$; Wilcoxon-Mann-Whitney test, $p=0.41$ ), or the number of branches $\left(\mathrm{d} 4 \mathrm{EGFP}^{+}: 17.5 \pm 4.75\right.$ branches, $n=6$;

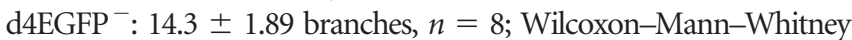
test, $p=0.59)$. Together, these results indicate that changes in IGC synaptic strength or number cannot explain the increased responses to glomerular stimulation in Arc-expressing IGCs.
Arc-expressing IGCs possess enhanced intrinsic excitability Lacking support for our initial hypothesis, we turned to an alternative, which was that Arc-expressing IGCs respond more strongly to VSN input stimulation due to changes in intrinsic properties. We used a systematic approach to assess possible intrinsic physiological differences in an unbiased way. We targeted whole-cell patch-clamp recordings to Arc-expressing and nonexpressing IGCs $4-8 \mathrm{~h}$ postbehavior and delivered a series of electrophysiological challenges in current and voltage clamp. Using automated algorithms (see Experimental procedures), we quantified 26 physiological characteristics covering a variety of intrinsic properties (Table 1). To capture the differences between Arc-expressing and nonexpressing IGCs, we performed cluster analysis on the 26-dimensional array of characteristics from 100 neurons that had undergone the same electrophysiological challenges (Fig. 6A,B). This collection of cells contained 26

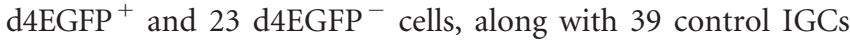
from mice that had not undergone behavioral challenges and 12 MCs (used as a control population; Fig. $6 A, B$ ). Four clusters were identified by this analysis. A total of $69.2 \%$ of all d4EGFP ${ }^{+}$IGCs were assigned to cluster 3 , where neurons exhibited sustained strong spiking activity in response to depolarization and lower levels of spike accommodation. Other intrinsic characteristics, including input resistance, resting membrane potential, and action potential threshold, were highly variable across cells in 
A

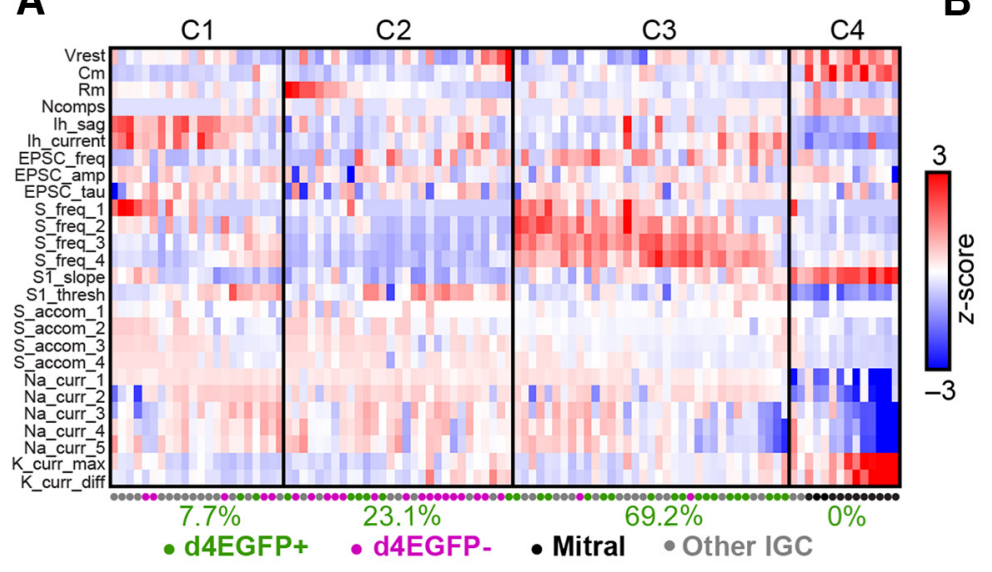

B

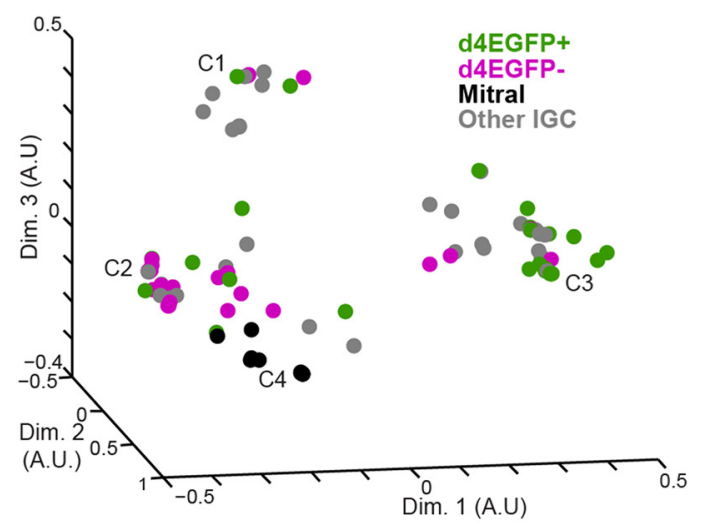

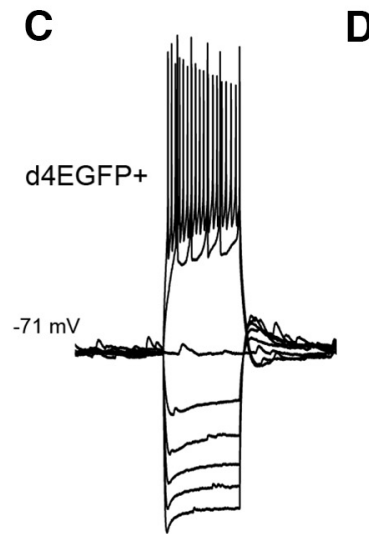
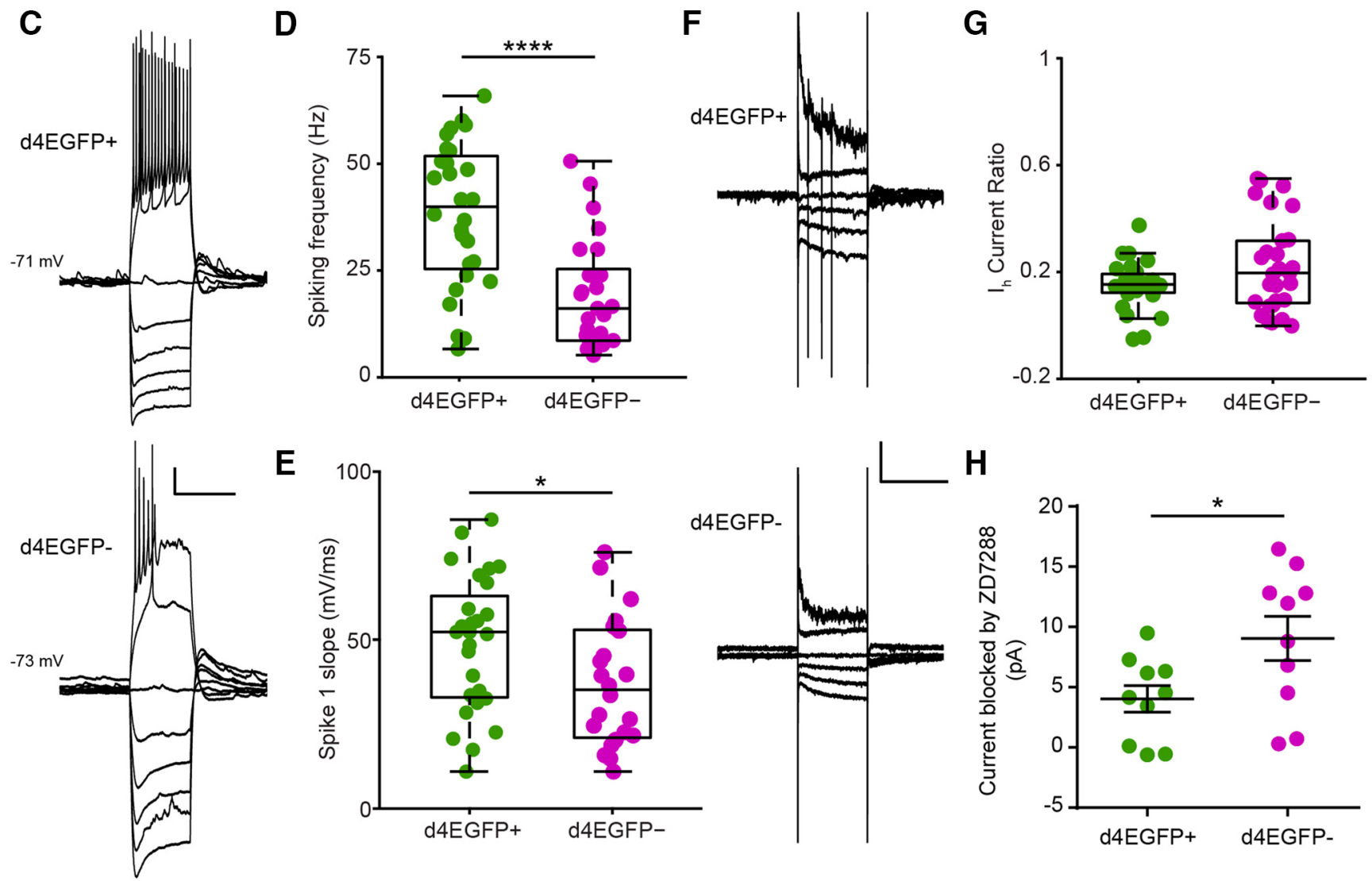

Figure 6. Arc-expressing IGCs are intrinsically more excitable than nonexpressing IGCS. A, Colorized heat map representation of 26 intrinsic descriptors (rows) across 100 AOB neurons (columns) that were subjected to current-clamp and voltage-clamp challenges. Solid vertical lines indicate divisions between identified clusters. Below each cluster is the percentage of all d4EGFP ${ }^{+}$IGCs within that cluster. B, Multidimensional scaling of relative differences across all 26 dimensions from $\boldsymbol{A}$ into three dimensions. Each individual colored point indicates a cell, and $C 1-C 4$ refer to the cluster definitions in $\boldsymbol{A}$. For $\boldsymbol{A}$ and $\boldsymbol{B}$ : d4EGFP ${ }^{+}$IGCS, $n=26 ;$ d4EGFP $^{-}$IGCS, $n=23 ; n=15$ animals; other IGCs, $n=39 ;$ mitral, $n=12 ; n=37$ animals. C, Sample traces for d4EGFP ${ }^{+}$and d4EGFP ${ }^{-}$ IGCs for current-clamp ramp challenges. Calibration: $10 \mathrm{mV}, 500 \mathrm{~ms} . D$, d4EGFP ${ }^{+} \mathrm{IGCs}$ exhibit significantly increased spiking frequency when depolarized by a current injection (d4EGFP ${ }^{+}, n=26$; d4EGFP ${ }^{-}, n=23$; Wilcoxon-Mann-Whitney test, $\left.p<0.0001\right)$. E, d4EGFP $^{+}$and d4EGFP ${ }^{-}$IGCs demonstrate increased maximal action potential slope (d4EGFP ${ }^{+}, n=26 ; \mathrm{d}^{-} \mathrm{EGFP}^{-}, n=23$;

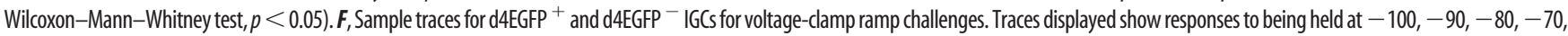
-40 , and $-20 \mathrm{mV}$. Calibration:50 pA, $500 \mathrm{~ms}$. G, $I_{\mathrm{H}}$ current ratio for d4EGFP ${ }^{+}$and d4EGFP ${ }^{-}$cells (d4EGFP ${ }^{+}, n=26$; d4EGFP ${ }^{-}, n=23$; Wilcoxon-Mann-Whitney test, $\left.p=0.24\right) . \boldsymbol{H}, I_{H}$ subtracted currents following $10 \mu \mathrm{m}$ ZD7288 application for d4EGFP ${ }^{+}$and d4EGFP ${ }^{-}$IGCs (d4EGFP ${ }^{+}$cells, $n=10 ;$ d4EGFP $^{-}$cells, $n=10 ; n=9$ mice; Wilcoxon-Mann-Whitney test, $\left.p<0.05\right) .{ }^{*} p<0.05,{ }^{* * * *} p<0.0001$.

this cluster, indicating that increased IGC firing frequency was not associated with a systematic change in these other properties.

In assessing individual intrinsic properties, few differed significantly between d4EGFP ${ }^{+}$and d4EGFP ${ }^{-}$IGCs (Fig. 6C-H). The most noteworthy individual characteristic was an increase in spiking frequency in response to strong somatic depolarization in Arcexpressing IGCs (Wilcoxon-Mann-Whitney test, $p<0.0001$; Fig.
6D). d4EGFP ${ }^{+}$IGCs demonstrated an increase in the maximal slope of initial action potentials (Wilcoxon-Mann-Whitney test, $p<$ 0.05; Fig. $6 E$ ), which was not a result of increased sodium current peak amplitudes $\left(\mathrm{d} 4 \mathrm{EGFP}^{+}, 2.33 \pm 0.22 \mathrm{nA}\right.$; d4EGFP ${ }^{-}, 2.02 \pm 0.14$ nA; Wilcoxon-Mann-Whitney test, $p=0.49$ ) or spike threshold $\left(\mathrm{d} 4 \mathrm{EGFP}^{+},-23.5 \pm 1.5 \mathrm{mV}\right.$; d4EGFP ${ }^{-},-23.0 \pm 1.3 \mathrm{mV}$; WilcoxonMann-Whitney test, $p=0.53$ ). 

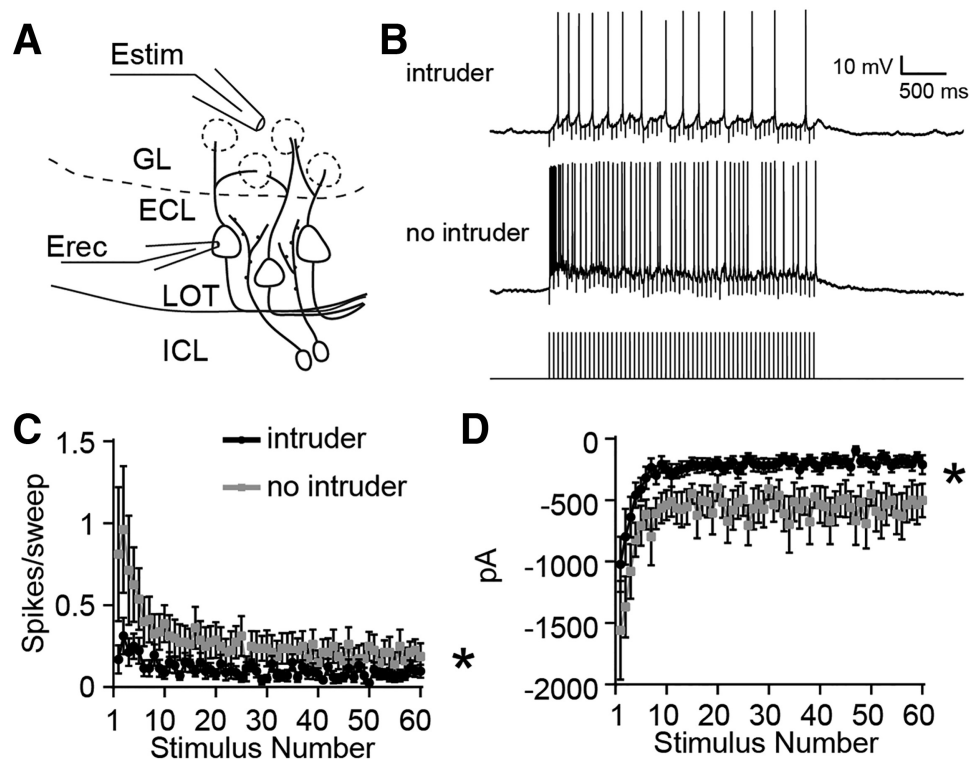

Figure 7. MCs show decreased excitation by glomerular stimulation following resident-intruder behavior. $\boldsymbol{A}$, Diagram illustrating experimental setup. Estim, Theta glass-stimulating electrode; Erec, recording electrode. $\boldsymbol{B}$, Sample MC responses to $3 \mathrm{~s}, 20$ $\mathrm{Hz}$ glomerular layer (GL) stimulation from residents that interacted with an intruder and control residents (no intruder). C, Per-stimulus spike probability in response to each pulse of $3 \mathrm{~s}, 20 \mathrm{~Hz}$ stimulation while the cell was artificially brought to the subthreshold potential of $-55 \mathrm{mV}$. Repeated-measures ANOVA, interaction between group and stimulus: $F_{(59,1298)}=2.45,{ }^{*} p<$ 0.0001. Behavior: $n=14$ cells, $n=4$ mice; no behavior: $n=10$ cells, $n=4$ mice. $D$, Peak current amplitude in response to $3 \mathrm{~s}$, $20 \mathrm{~Hz}$ stimulation while the cell was held at $-40 \mathrm{mV}$. Repeated-measures ANOVA, main effect of group: $F_{(1,22)}=8.49,{ }^{*} p=$ 0.008. Behavior: $n=13$ cells, $n=4$ mice; no behavior: $n=9$ cells, $n=4$ mice.

Arc-expressing IGCs also exhibited a slight decrease in $I_{\mathrm{H}}$ currents (Fig. 6G), which we confirmed by measuring the currents blocked by the hyperpolarization-activated cyclic nucleotidegated $(\mathrm{HCN})$ channel antagonist ZD7288 (10 $\mu \mathrm{M}$; WilcoxonMann-Whitney, $p<0.05$; Fig. $6 H$ ). Because IGCs have high input resistance $(1.0 \pm 0.17 \mathrm{G} \Omega ; n=54 \mathrm{IGCs})$, small-amplitude $I_{\mathrm{H}}$ currents resulted in prominent depolarization ("sag" potential) measured at the soma $\left(\mathrm{d} 4 \mathrm{EGFP}^{+}, 5.81 \pm 0.62 \mathrm{mV}\right.$;

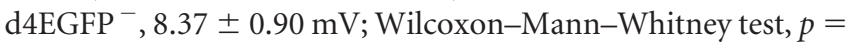
$0.11)$. These basic $I_{\mathrm{H}}$ measurements were made after step hyperpolarization from a steady-state membrane potential near -70 $\mathrm{mV}$, which may have obscured $I_{\mathrm{H}}$ conductances open near IGC resting potential. To measure the contributions of such conductances, we subtracted $I_{\mathrm{H}}$ sag potentials (reflecting conductances activated by the transition from approximately -70 to approximately $-125 \mathrm{mV}$ ) from rebound depolarizations that occurred after the hyperpolarizing pulses (reflecting all $I_{\mathrm{H}}$ conductances). This analysis revealed a larger relative contribution of $I_{\mathrm{H}}$ conductances near resting potential in $\mathrm{d}_{4} \mathrm{EGFP}^{+}$IGCs compared with d4EGFP $^{-}$IGCs, suggesting a slight shift in the voltage dependence of activation of HCN channels $\left(\mathrm{d} 4 \mathrm{EGFP}^{+}, 1.33 \pm 0.57 \mathrm{mV}\right.$; d4EGFP ${ }^{-}, 0.23 \pm 0.47 \mathrm{mV}$; Wilcoxon-Mann-Whitney test, $p=0.059$ ). At face value, these $I_{\mathrm{H}}$ results were somewhat surprising. However, the modulation of $I_{\mathrm{H}}$ has been reported in Arc-dependent plasticity elsewhere in the brain (Shah, 2014). In many cases, the downregulation of $I_{\mathrm{H}}$ has been associated with increased neuronal excitability (Poolos et al., 2002; Brager and Johnston, 2007; Campanac et al., 2008; Yi et al., 2016).

It may be possible that $A r c$ is required for the expression of experience-dependent increases in IGC excitability. To investigate this hypothesis, we used Arc-d2EGFP knock-in/knock-out animals (Wang et al., 2006). In $A r c^{-1-}$ animals, d2EGFP is expressed in neurons that would normally express Arc. We repeated our intrinsic electrophysiological assay in acute slices taken from
$\mathrm{Arc}^{-1-}$ male residents. $\mathrm{d} 2 \mathrm{EGFP}^{+}$IGCs in $\mathrm{Arc}^{-1-}$ mice showed no differences in maximum spiking frequency $\left(\mathrm{d} 2 \mathrm{EGFP}^{+}, 34.34 \pm\right.$ $4.64 \mathrm{~Hz}, n=16$; d2EGFP ${ }^{-}, 27.25 \pm 4.38$ $\mathrm{Hz}, n=12$; Wilcoxon-Mann-Whitney test, $p=0.30), \quad I_{\mathrm{H}}$ sag potential $\left(\mathrm{d} 2 \mathrm{EGFP}^{+}, 7.15 \pm 0.71 \mathrm{mV}, n=20\right.$;

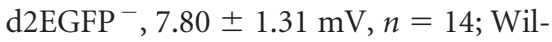
coxon-Mann-Whitney test, $p=0.45)$, or $I_{\mathrm{H}}$ currents $\left(I_{\mathrm{H}}\right.$ current ratio: d2EGFP ${ }^{+}$, $0.173 \pm 0.025, n=17$; d2EGFP ${ }^{-}, 0.155 \pm$ $0.029, n=14$; Wilcoxon-Mann-Whitney test, $p=0.80$ ) compared with $\mathrm{d} 2 \mathrm{EGFP}^{-}$ IGCs from the same slices. These results suggest that $A r c$ is required for the observed differences in excitability between Arc-expressing and nonexpressing IGCs following male-male social interaction.

\section{MC responses to glomerular stimulation are suppressed following behavior}

The increased excitability of Arcexpressing IGCs suggests that AOB MCs may experience stimulus-associated suppression following resident-intruder encounters. To test this hypothesis, we measured the responses of posterior $\mathrm{AOB}$ MCs to glomerular layer stimulation during the same $4-8 \mathrm{~h}$ postbehavior time window used in IGC recordings (Fig. 7). MCs in current clamp were depolarized via steady-state current injections to $-55 \mathrm{mV}$ (just below the action potential threshold) and exposed to $3 \mathrm{~s}, 20 \mathrm{~Hz}$ glomerular layer stimulation (Fig. $7 \mathrm{~B}, \mathrm{C}$ ). We observed less evoked spiking activity in MCs in AOB slices taken from postbehavior resident males than no-intruder controls (repeatedmeasures ANOVA, interaction between group and stimulus: $F_{(59,1298)}=2.45, p<0.0001 ; n=13$ cells, 4 mice for "intruder" group; $n=9$ cells, 4 mice for "no intruder" group, Fig. $7 B, C$ ). Voltage-clamp experiments from these same cells held at -40 $\mathrm{mV}$ revealed suppressed net inward current during the stimulus trains (repeated-measures ANOVA, main effect of group: $F_{(1,22)}$ $=8.49, p=0.008$; Fig. $7 D$ ). We observed no differences in net inward current when cells were held at $-50 \mathrm{mV}$ (nearer $\mathrm{Cl}^{-}$ reversal potential), indicating that the results at $-40 \mathrm{mV}$ reflect the influence of increased outward currents (repeated-measures ANOVA, no main effect of group: $\left.F_{(1,22)}=0.07, p=0.80\right)$. We did not observe increased MC intrinsic excitability postbehavior (MC maximum spiking frequency: postbehavior, $48.1 \pm 2.5 \mathrm{~Hz}$; control, $40.2 \pm 2.1 \mathrm{~Hz}$; Wilcoxon-Mann-Whitney test, $p=0.13$ ) but did involve a small decrease in $I_{\mathrm{H}}$ currents (normalized $I_{\mathrm{H}}$ current ratio, $0.0342 \pm 0.003$; postbehavior $I_{\mathrm{H}}$ current ratio, $0.047 \pm 0.005$; Wilcoxon-Mann-Whitney test, $p=0.035)$. Importantly, these currents are much smaller than those observed in IGCs, which is consistent with recent observations in mitral cells (Gorin et al., 2016). These results confirm that male-male social chemosensory encounters are associated with subsequent $\mathrm{MC}$ suppression, which is consistent with an experience-dependent increase in IGC-MC inhibition.

\section{Discussion}

The AOB remains a mysterious sensory circuit. It is often considered to be a relay station for information about environmental 
pheromones and kairomones, but there is ample evidence that the $\mathrm{AOB}$ also participates in experience-dependent plasticity (Brennan, 2009). Experience-dependent plasticity in the AOB has been studied almost exclusively in the female rodent $\mathrm{AOB}$ in the context of mating (Binns and Brennan, 2005; Brennan and Kendrick, 2006), but there are many other rodent behaviors that are strongly influenced by the AOS (Maruniak et al., 1986; Wysocki and Lepri, 1991; Stowers et al., 2002; Kimchi et al., 2007; Papes et al., 2010). The principal motivation for this work was a desire to learn more about experience-dependent $\mathrm{AOB}$ plasticity in the context of nonmating AOS-mediated behaviors.

We specifically chose to study the resident-intruder territorial aggression paradigm because it is a male-typical AOS-dependent behavior that induces robust IEG activation in the AOB (Maruniak et al., 1986; Wysocki and Lepri, 1991; Kumar et al., 1999; Stowers et al., 2002). Arc is upregulated in male and female rodent AOB IGCs following mating (Matsuoka et al., 2002a,b, 2003), suggesting that Arc-expressing IGCs may underlie the increased $\mathrm{AOB}$ inhibition observed in this context (Kaba and Keverne, 1988; Brennan et al., 1990). Our results show that Arc is selectively transcribed and translated in posterior AOB IGCs of male mice following male-male social chemosensory encounters (Figs. 1, 2). Arc upregulation in AOB IGCs after the residentintruder assay requires $A O S$ chemosensory signaling, indicating that this effect is not caused by brain processes (e.g., centrifugal neuromodulation) associated with other sensory systems (Figs. 2, 3).

The specific neurophysiological changes reported in Arcexpressing neurons in other brain regions vary widely and are often subtle (Wang et al., 2006; Ploski et al., 2008; Shepherd and Bear, 2011; Jakkamsetti et al., 2013). For example, Arc-deficient pyramidal neurons in visual cortex have an overall reduction in their orientation selectivity but retain experience-dependent refinement of this selectivity (Wang et al., 2006). In the context of novel environment exploration, Arc-expressing hippocampal pyramidal neurons do not show outright synaptic depression but instead are primed for mGluR-dependent LTD (Jakkamsetti et al., 2013). In the AOB, Arc upregulation is conspicuously absent in projecting MCs (Figs. 1, 2, 3). IGCs are physiologically and morphologically different from most of the principal cell types in which Arc has been studied. Specifically, IGCs are axonless and use reciprocal dendrodendritic synapses to communicate with MCs (Jia et al., 1999; Taniguchi and Kaba, 2001). IGCs also experience significant cellular turnover in adulthood and are replenished by adult-born neurons that migrate via the rostral migratory stream (Alvarez-Buylla and Garcia-Verdugo, 2002). The selective capacity of IGCs to upregulate $A r c$ in response to social chemosensory experience suggests that these interneurons may be primary drivers of $\mathrm{AOB}$ experience-dependent plasticity.

There are several genetic tools for labeling and manipulating Arc-expressing cells in living mouse brain tissue (Wang et al., 2006; Grinevich et al., 2009; Guenthner et al., 2013; Kawashima et al., 2014). We specifically chose Arc-d4EGFP-BAC reporter mice for our initial physiological experiments for two reasons. First, endogenous Arc expression in these mice is unperturbed. Second, the half-life of the d4EGFP reporter allowed us to visualize Arcexpressing cells in acute slices for several hours following behavior. Arc-d2EGFP knock-in/knock-out mice remain a helpful tool for exploring the Arc dependence of various forms of neuronal plasticity. However, experiments involving these mice use Arcpositive controls that are haploinsufficient for Arc and limit targeted physiology experiments to shorter time windows.

Previous studies of AOB IGC function used pharmacology to approximate the conditions present during salient social events
(Araneda and Firestein, 2006; Smith et al., 2009, 2015; Taniguchi et al., 2013). These studies revealed important features of IGC neuromodulation but did not investigate the cellular and synaptic changes that occur in IGCs activated by bona fide social behaviors. In Arc-d4EGFP-BAC mice, Arc expression in IGCs after resident-intruder encounters correlates with increased activation by sensory input (Fig. 4) and increased intrinsic excitability (Fig. 6). Arc expression has been associated with glutamate receptor trafficking in other contexts (Chowdhury et al., 2006; Shepherd et al., 2006; Waung et al., 2008). However, our data show that the increased network excitability of Arc-expressing IGCs is not related to an increase in EPSC frequency or amplitude, nor is there evidence of significant upregulation in the number of dendritic spines (Fig. 5). These results were somewhat surprising in light of previous work showing an increased size of the postsynaptic density on IGC dendrites in female mice $1 \mathrm{~d}$ after mating, suggesting increased excitatory drive on IGCs (Matsuoka et al., 2004). However, our experiments took place both in a different behavioral context and at an earlier time point, which could indicate that different mechanisms or time courses are present following male-male social encounters. The increased excitability seen in Arc-expressing cells in d4EGFP mice was not observed in $\mathrm{Arc}^{-1-}$ mice from the Arc-d2EGFP strain. This indicates that Arc participates in the intrinsic differences in AOB IGCs seen after resident-intruder encounters. Collectively, these data suggest that Arc expression in IGCs contributes to an increased intrinsic capacity to respond to sensory input.

IGCs do not receive direct excitation from VSN terminals in the AOB glomerular layer but are instead activated by glutamate release from MCs at reciprocal dendrodendritic synapses (Jia et al., 1999; Taniguchi and Kaba, 2001). MCs do not demonstrate experience-dependent increases in intrinsic excitability following resident-intruder encounters, suggesting that the increased IGC activation is specific to the IGC postsynaptic response. However, it is also possible that a change in presynaptic function in the MCs providing input to $A r c$-expressing IGCs contributes to this effect. To approach this question will require tools that label both Arcexpressing IGCs and their connected MCs in living tissue.

In our investigation of the intrinsic differences between Arcexpressing and nonexpressing cells, we used methods aimed at objectively classifying cells based on the expression of 26 specific characteristics. Arc-expressing and nonexpressing cells were segregated into clusters that differed in their capacity to sustain highfrequency spiking (Fig. 6). The increase in excitability was not a result of changes to voltage-gated sodium channel threshold, sodium current amplitudes, or macroscopic changes to voltagegated potassium currents. However, this analysis did reveal a trend for Arc-expressing IGCs to possess smaller $I_{\mathrm{H}}$ currents, which we confirmed pharmacologically (Fig. 6). HCN channel expression has been noted in the AOB and in IGCs, but their specific role in $\mathrm{AOB}$ circuit function has not yet been determined (Hu et al., 2016). $I_{\mathrm{H}}$ is active at resting membrane potential and gives rise to rebound depolarization after relief from transient hyperpolarization (Robinson and Siegelbaum, 2003; Biel et al., 2009). At face value, the observed decrease in $I_{\mathrm{H}}$ is at odds with the increase in intrinsic excitability seen in Arc-expressing IGCs. However, several other studies have shown that plasticity-induced decreases in $I_{\mathrm{H}}$ are associated with increases in excitability (Poolos et al., 2002; Brager and Johnston, 2007; Campanac et al., 2008; Yi et al., 2016). One potential factor in the apparent excitatory influence of decreased $I_{\mathrm{H}}$ could be a shift in the voltage dependence of HCN channel activation, leading to an increased number of HCN channels that are open at rest. Overall, our results suggest 
that experience-dependent plasticity modulates IGC $I_{\mathrm{H}}$ currents, perhaps selectively in postsynaptic/dendritic structures. (Lörincz et al., 2002; Yi et al., 2016).

We confirmed that posterior MC activity is suppressed in $\mathrm{AOB}$ slices from resident mice following the resident-intruder assay (Fig. 7). This observation supports the hypothesis that experience-dependent upregulation of IGC excitability in Arcexpressing cells contributes to MC suppression. The effects were relatively modest but were achieved despite lacking an experiencedependent marker to select for MCs that were active during the resident-intruder encounter. It is possible that this limitation precluded us from identifying other physiological changes in MCs that are induced following male-male social interaction.

The observed increases in IGC intrinsic excitability and MC suppression are present for at least $8 \mathrm{~h}$ following behavior. This suggests that MC activation upon re-exposure to the same male during this time window would be decreased, which may result in a change in male-male social interactions. In the context of the Bruce Effect, pheromonal learning is $\mathrm{AOB}$ dependent and can persist for many weeks (Brennan and Keverne, 1997). It may be the case that the AOS refines male-male social interactions over similar time courses, but the specific behavioral impacts and time courses of any effects remain to be elucidated. In sum, these data reveal that $\mathrm{AOB}$ experience-dependent plasticity involves Arc upregulation in IGCs, which results in increased MC inhibition through the upregulation of IGC intrinsic excitability. Furthermore, our data show that inhibitory plasticity in the AOB occurs across social contexts and is a general feature of the AOS.

\section{References}

Alvarez-Buylla A, Garcia-Verdugo JM (2002) Neurogenesis in adult subventricular zone. J Neurosci 22:629-634. Medline

Araneda RC, Firestein S (2006) Adrenergic enhancement of inhibitory transmission in the accessory olfactory bulb. J Neurosci 26:3292-3298. CrossRef Medline

Belluscio L, Koentges G, Axel R, Dulac C (1999) A map of pheromone receptor activation in the mammalian brain. Cell 97:209-220. CrossRef Medline

Biel M, Wahl-Schott C, Michalakis S, Zong X (2009) Hyperpolarizationactivated cation channels: from genes to function. Physiol Rev 89:847885. CrossRef Medline

Binns KE, Brennan PA (2005) Changes in electrophysiological activity in the accessory olfactory bulb and medial amygdala associated with mate recognition in mice. Eur J Neurosci 21:2529-2537. CrossRef Medline

Bolte S, Cordelières FP (2006) A guided tour into subcellular colocalization analysis in light microscopy. J Microsc 224:213-232. CrossRef Medline

Brager DH, Johnston D (2007) Plasticity of intrinsic excitability during long-term depression is mediated through mGluR-dependent changes in $I_{\mathrm{h}}$ in hippocampal CA1 pyramidal neurons. J Neurosci 27:13926-13937. CrossRef Medline

Brennan PA (2009) Outstanding issues surrounding vomeronasal mechanisms of pregnancy block and individual recognition in mice. Behav Brain Res 200:287-294. CrossRef Medline

Brennan PA, Kendrick KM (2006) Mammalian social odours: attraction and individual recognition. Philos Trans R Soc Lond B Biol Sci 361:20612078. CrossRef Medline

Brennan PA, Keverne EB (1997) Neural mechanisms of mammalian olfactory learning. Prog Neurobiol 51:457-481. CrossRef Medline

Brennan PA, Kendrick KM, Keverne EB (1995) Neurotransmitter release in the accessory olfactory bulb during and after the formation of an olfactory memory in mice. Neuroscience 69:1075-1086. CrossRef Medline

Brennan P, Kaba H, Keverne EB (1990) Olfactory recognition: a simple memory system. Science 250:1223-1226. CrossRef Medline

Bruce HM (1959) An exteroceptive block to pregnancy in the mouse. Nature 184:105. CrossRef Medline

Bruce HM, Parrott DM (1960) Role of olfactory sense in pregnancy block by strange males. Science 131:1526. CrossRef Medline

Campanac E, Daoudal G, Ankri N, Debanne D (2008) Downregulation of dendritic $I_{\mathrm{h}}$ in CA1 pyramidal neurons after LTP. J Neurosci 28:86358643. CrossRef Medline

Chamero P, Marton TF, Logan DW, Flanagan K, Cruz JR, Saghatelian A, Cravatt BF, Stowers L (2007) Identification of protein pheromones that promote aggressive behaviour. Nature 450:899-902. CrossRef Medline

Chowdhury S, Shepherd JD, Okuno H, Lyford G, Petralia RS, Plath N, Kuhl D, Huganir RL, Worley PF (2006) Arc/Arg3.1 interacts with the endocytic machinery to regulate AMPA receptor trafficking. Neuron 52:445459. CrossRef Medline

Ferrero DM, Moeller LM, Osakada T, Horio N, Li Q, Roy DS, Cichy A, Spehr M, Touhara K, Liberles SD (2013) A juvenile mouse pheromone inhibits sexual behaviour through the vomeronasal system. Nature 502:368-371. CrossRef Medline

Golowasch J, Thomas G, Taylor AL, Patel A, Pineda A, Khalil C, Nadim F (2009) Membrane capacitance measurements revisited: dependence of capacitance value on measurement method in nonisopotential neurons. J Neurophysiol 102:2161-2175. CrossRef Medline

Gorin M, Tsitoura C, Kahan A, Watznauer K, Drose DR, Arts M, Mathar R, O'Connor S, Hanganu-Opatz IL, Ben-Shaul Y, Spehr M (2016) Interdependent conductances drive infraslow intrinsic rhythmogenesis in a subset of accessory olfactory bulb projection neurons. J Neurosci 36 : 3127-3144. CrossRef Medline

Grinevich V, Kolleker A, Eliava M, Takada N, Takuma H, Fukazawa Y, Shigemoto R, Kuhl D, Waters J, Seeburg PH, Osten P (2009) Fluorescent Arc/Arg3.1 indicator mice: a versatile tool to study brain activity changes in vitro and in vivo. J Neurosci Methods 184:25-36. CrossRef Medline

Guenthner CJ, Miyamichi K, Yang HH, Heller HC, Luo L (2013) Permanent genetic access to transiently active neurons via TRAP: targeted recombination in active populations. Neuron 78:773-784. CrossRef Medline

Guthrie K, Rayhanabad J, Kuhl D, Gall C (2000) Odors regulate Arc expression in neuronal ensembles engaged in odor processing. Neuroreport 11: 1809-1813. CrossRef Medline

Hendrickson RC, Krauthamer S, Essenberg JM, Holy TE (2008) Inhibition shapes sex selectivity in the mouse accessory olfactory bulb. J Neurosci 28:12523-12534. CrossRef Medline

Hu R, Ferguson KA, Whiteus CB, Meijer DH, Araneda RC (2016) Hyperpolarization-activated currents and subthreshold resonance in granule cells of the olfactory bulb. Eneuro 3:e0197-16.2016. CrossRef Medline

Jakkamsetti V, Tsai NP, Gross C, Molinaro G, Collins KA, Nicoletti F, Wang KH, Osten P, Bassell GJ, Gibson JR, Huber KM (2013) Experienceinduced Arc/Arg3.1 primes CA1 pyramidal neurons for metabotropic glutamate receptor-dependent long-term synaptic depression. Neuron 80:72-79. CrossRef Medline

Jia C, Chen WR, Shepherd GM (1999) Synaptic organization and neurotransmitters in the rat accessory olfactory bulb. J Neurophysiol 81:345355. Medline

Kaba H, Keverne EB (1988) The effect of microinfusions of drugs into the accessory olfactory bulb on the olfactory block to pregnancy. Neuroscience 25:1007-1011. CrossRef Medline

Kawashima T, Kitamura K, Suzuki K, Nonaka M, Kamijo S, Takemoto-Kimura S, Kano M, Okuno H, Ohki K, Bito H (2013) Functional labeling of neurons and their projections using the synthetic activity-dependent promoter E-SARE. Nat Methods 10:889-895. CrossRef Medline

Kawashima T, Okuno H, Bito H (2014) A new era for functional labeling of neurons: activity-dependent promoters have come of age. Front Neural Circuits 8:37. CrossRef Medline

Kim Y, Venkataraju KU, Pradhan K, Mende C, Taranda J, Turaga SC, Arganda-Carreras I, Ng L, Hawrylycz MJ, Rockland KS, Seung HS, Osten P (2015) Mapping social behavior-induced brain activation at cellular resolution in the mouse. Cell Rep 10:292-305. CrossRef Medline

Kimchi T, Xu J, Dulac C (2007) A functional circuit underlying male sexual behaviour in the female mouse brain. Nature 448:1009-1014. CrossRef Medline

Kumar A, Dudley CA, Moss RL (1999) Functional dichotomy within the vomeronasal system: distinct zones of neuronal activity in the accessory olfactory bulb correlate with sex-specific behaviors. J Neurosci 19:RC32. Medline

Larriva-Sahd J (2008) The accessory olfactory bulb in the adult rat: a cytological study of its cell types, neuropil, neuronal modules, and interactions with the main olfactory system. J Comp Neurol 510:309-350. CrossRef Medline

Leinders-Zufall T, Ishii T, Chamero P, Hendrix P, Oboti L, Schmid A, Kircher 
S, Pyrski M, Akiyoshi S, Khan M, Vaes E, Zufall F, Mombaerts P (2014) A family of nonclassical class I MHC genes contributes to ultrasensitive chemodetection by mouse vomeronasal sensory neurons. J Neurosci 34: 5121-5133. CrossRef Medline

Liberles SD (2014) Mammalian pheromones. Annu Rev Physiol 76:151175. CrossRef Medline

Longair MH, Baker DA, Armstrong JD (2011) Simple Neurite Tracer: open source software for reconstruction, visualization and analysis of neuronal processes. Bioinformatics 27:2453-2454. CrossRef Medline

Lörincz A, Notomi T, Tamás G, Shigemoto R, Nusser Z (2002) Polarized and compartment-dependent distribution of HCN1 in pyramidal cell dendrites. Nat Neurosci 5:1185-1193. CrossRef Medline

Madisen L, Zwingman TA, Sunkin SM, Oh SW, Zariwala HA, Gu H, Ng LL, Palmiter RD, Hawrylycz MJ, Jones AR, Lein ES, Zeng H (2010) A robust and high-throughput Cre reporting and characterization system for the whole mouse brain. Nat Neurosci 13:133-140. CrossRef Medline

Maruniak JA, Wysocki CJ, Taylor JA (1986) Mediation of male mouse urine marking and aggression by the vomeronasal organ. Physiol Behav 37:655657. CrossRef Medline

Matsuoka M, Yamagata K, Sugiura H, Yoshida-Matsuoka J, Norita M, Ichikawa M (2002a) Expression and regulation of the immediate-early gene product Arc in the accessory olfactory bulb after mating in male rat. Neuroscience 111:251-258. CrossRef Medline

Matsuoka M, Yoshida-Matsuoka J, Sugiura H, Yamagata K, Ichikawa M, Norita M (2002b) Mating behavior induces differential Arc expression in the main and accessory olfactory bulbs of adult rats. Neurosci Lett 335:111-114. CrossRef Medline

Matsuoka M, Yoshida-Matsuoka J, Yamagata K, Sugiura H, Ichikawa M, Norita M (2003) Rapid induction of Arc is observed in the granule cell dendrites in the accessory olfactory bulb after mating. Brain Res 975:189195. CrossRef Medline

Matsuoka M, Kaba H, Moriya K, Yoshida-Matsuoka J, Costanzo RM, Norita M, Ichikawa M (2004) Remodeling of reciprocal synapses associated with persistence of long-term memory. Eur J Neurosci 19:1668-1672. CrossRef Medline

Meeks JP, Jiang X, Mennerick S (2005) Action potential fidelity during normal and epileptiform activity in paired soma-axon recordings from rat hippocampus. J Physiol 566:425-441. CrossRef Medline

Meeks JP, Arnson HA, Holy TE (2010) Representation and transformation of sensory information in the mouse accessory olfactory system. Nat Neurosci 13:723-730. CrossRef Medline

Nunez-Parra A, Maurer RK, Krahe K, Smith RS, Araneda RC (2013) Disruption of centrifugal inhibition to olfactory bulb granule cells impairs olfactory discrimination. Proc Natl Acad Sci U S A 110:14777-14782. CrossRef Medline

Oettl LL, Ravi N, Schneider M, Scheller MF, Schneider P, Mitre M, da Silva Gouveia M, Froemke RC, Chao MV, Young WS, Meyer-Lindenberg A, Grinevich V, Shusterman R, Kelsch W (2016) Oxytocin enhances social recognition by modulating cortical control of early olfactory processing. Neuron 90:609-621. CrossRef Medline

Omura M, Mombaerts P (2014) Trpc2-expressing sensory neurons in the main olfactory epithelium of the mouse. Cell Rep 8:583-595. CrossRef Medline

Pankevich DE, Baum MJ, Cherry JA (2004) Olfactory sex discrimination persists, whereas the preference for urinary odorants from estrous females disappears in male mice after vomeronasal organ removal. J Neurosci 24:9451-9457. CrossRef Medline

Papes F, Logan DW, Stowers L (2010) The vomeronasal organ mediates interspecies defensive behaviors through detection of protein pheromone homologs. Cell 141:692-703. CrossRef Medline

Pérez-Gómez A, Bleymehl K, Stein B, Pyrski M, Birnbaumer L, Munger SD, Leinders-Zufall T, Zufall F, Chamero P (2015) Innate predator odor aversion driven by parallel olfactory subsystems that converge in the ventromedial hypothalamus. Curr Biol 25:1340-1346. CrossRef Medline

Plath N, Ohana O, Dammermann B, Errington ML, Schmitz D, Gross C, Mao X, Engelsberg A, Mahlke C, Welzl H, Kobalz U, Stawrakakis A, Fernandez E, Waltereit R, Bick-Sander A, Therstappen E, Cooke SF, Blanquet V, Wurst W, Salmen B, et al (2006) Arc/Arg3.1 is essential for the consolidation of synaptic plasticity and memories. Neuron 52:437-444. CrossRef Medline

Ploski JE, Pierre VJ, Smucny J, Park K, Monsey MS, Overeem KA, Schafe GE
(2008) The activity-regulated cytoskeletal-associated protein (Arc/Arg3.1) is required for memory consolidation of pavlovian fear conditioning in the lateral amygdala. J Neurosci 28:12383-12395. CrossRef Medline

Poolos NP, Migliore M, Johnston D (2002) Pharmacological upregulation of h-channels reduces the excitability of pyramidal neuron dendrites. Nat Neurosci 5:767-774. CrossRef Medline

Robinson RB, Siegelbaum SA (2003) Hyperpolarization-activated cation currents: from molecules to physiological function. Annu Rev Physiol 65:453-480. CrossRef Medline

Rodriguez I, Feinstein P, Mombaerts P (1999) Variable patterns of axonal projections of sensory neurons in the mouse vomeronasal system. Cell 97:199-208. CrossRef Medline

Rothermel M, Carey RM, Puche A, Shipley MT, Wachowiak M (2014) Cholinergic inputs from Basal forebrain add an excitatory bias to odor coding in the olfactory bulb. J Neurosci 34:4654-4664. CrossRef Medline

Scalia F, Winans SS (1975) The differential projections of the olfactory bulb and accessory olfactory bulb in mammals. J Comp Neurol 161:31-55. CrossRef Medline

Shah MM (2014) Cortical HCN channels: function, trafficking and plasticity. J Physiol 592:2711-2719. CrossRef Medline

Shakhawat AM, Gheidi A, Hou Q, Dhillon SK, Marrone DF, Harley CW, Yuan Q (2014) Visualizing the engram: learning stabilizes odor representations in the olfactory network. J Neurosci 34:15394-15401. CrossRef Medline

Shepherd JD, Bear MF (2011) New views of Arc, a master regulator of synaptic plasticity. Nat Neurosci 14:279-284. CrossRef Medline

Shepherd JD, Rumbaugh G, Wu J, Chowdhury S, Plath N, Kuhl D, Huganir RL, Worley PF (2006) Arc/Arg3.1 mediates homeostatic synaptic scaling of AMPA receptors. Neuron 52:475-484. CrossRef Medline

Shipley MT, Halloran FJ, de la Torre J (1985) Surprisingly rich projection from locus coeruleus to the olfactory bulb in the rat. Brain Res 329:294299. CrossRef Medline

Smith RS, Weitz CJ, Araneda RC (2009) Excitatory actions of noradrenaline and metabotropic glutamate receptor activation in granule cells of the accessory olfactory bulb. J Neurophysiol 102:1103-1114. CrossRef Medline

Smith RS, Hu R, DeSouza A, Eberly CL, Krahe K, Chan W, Araneda RC (2015) Differential muscarinic modulation in the olfactory bulb. J Neurosci 35:10773-10785. CrossRef Medline

Stowers L, Holy TE, Meister M, Dulac C, Koentges G (2002) Loss of sex discrimination and male-male aggression in mice deficient for TRP2. Science 295:1493-1500. CrossRef Medline

Taniguchi M, Kaba H (2001) Properties of reciprocal synapses in the mouse accessory olfactory bulb. Neuroscience 108:365-370. CrossRef Medline

Taniguchi M, Yokoi M, Shinohara Y, Okutani F, Murata Y, Nakanishi S, Kaba H (2013) Regulation of synaptic currents by mGluR2 at reciprocal synapses in the mouse accessory olfactory bulb. Eur J Neurosci 37:351-358. CrossRef Medline

Vazdarjanova A, Ramirez-Amaya V, Insel N, Plummer TK, Rosi S, Chowdhury S, Mikhael D, Worley PF, Guzowski JF, Barnes CA (2006) Spatial exploration induces ARC, a plasticity-related immediate-early gene, only in calcium/calmodulin-dependent protein kinase II-positive principal excitatory and inhibitory neurons of the rat forebrain. J Comp Neurol 498: 317-329. CrossRef Medline

Vousden DA, Epp J, Okuno H, Nieman BJ, van Eede M, Dazai J, Ragan T, Bito H, Frankland PW, Lerch JP, Henkelman RM (2015) Whole-brain mapping of behaviourally induced neural activation in mice. Brain Struct Funct 220:2043-2057. CrossRef Medline

Wang KH, Majewska A, Schummers J, Farley B, Hu C, Sur M, Tonegawa S (2006) In vivo two-photon imaging reveals a role of arc in enhancing orientation specificity in visual cortex. Cell 126:389-402. CrossRef Medline

Waung MW, Pfeiffer BE, Nosyreva ED, Ronesi JA, Huber KM (2008) Rapid translation of Arc/Arg3.1 selectively mediates mGluR-dependent LTD through persistent increases in AMPAR endocytosis rate. Neuron 59:8497. CrossRef Medline

Wysocki CJ, Lepri JJ (1991) Consequences of removing the vomeronasal organ. J Steroid Biochem Mol Biol 39:661-669. CrossRef Medline

Yi F, Danko T, Botelho SC, Patzke C, Pak C, Wernig M, Südhof TC (2016) Autism-associated SHANK3 haploinsufficiency causes Ih channelopathy in human neurons. Science 352:aaf2669. CrossRef Medline 